\title{
Aristocrats and Agriculture in the Middle and Late Republic*
}

\author{
NATHAN ROSENSTEIN
}

\section{INTRODUCTION}

Agriculture was the economic backbone of the Republican aristocracy: so much has long seemed beyond question. Landownership was safe, conferred prestige, and associated its possessors with the moral foundations of Roman greatness. ${ }^{1}$ While members of the senatorial class, particularly the nobility, may have dabbled in money-lending, commerce, or other forms of non-agricultural enterprise, they are supposed to have derived the bulk of their incomes from their farms. ${ }^{2}$ Hence, the richer they became, the larger their holdings grew as the lack of other suitable investments and the attractions of agriculture led them to plough their cash into land. ${ }^{3}$ This truism, in turn, has long played a central role in a powerful and immensely influential account of the social turmoil in the late Republic and Italy's concomitant transformation into a slave-economy. As is well-known, this theory holds that the Senate's incessant wars during the second and first centuries B.C. ruined the Roman and Italian small farmers who fought them, forcing them to sell or abandon their farms in the face of economic pressure or even violence from their wealthier neighbours. Prominent among those neighbours were the Republic's political élite, flush with the spoils of victory and needing to provide the financial wherewithal that they and their progeny would require to compete in an increasingly expensive political arena. ${ }^{4}$ So they snapped up vast tracts of land on which they established plantations manned by the slaves that Rome's victories had made a cheap and abundant source of labour, immune from the threat of conscription for long wars overseas. These estates in turn produced the wine, oil, grain and other products needed to feed Italy's burgeoning urban population, swollen by a steady influx of the very same small farmers whom the aristocracy's foreign policy and investment strategies had forced off their land. Having fought for their own displacement, Italy's ex-soldiers now functioned, in a grim irony, as the consumers of the food grown by the

\footnotetext{
Versions of this paper were presented at the 2005 meeting of the American Philological Association and at Agricoltura e scambi nell'Italia tardo repubblicana in Rome, 2008. I would like to offer my thanks to all those who offered comments on those occasions as well as to Walter Scheidel, Wim Jongman and to the Editor and the anonymous readers for the $J R S$ whose suggestions and criticisms have greatly improved it. For its remaining imperfections I alone am responsible. This study is dedicated to my teacher and friend, Erich Gruen, in honour of his retirement from the University of California, Berkeley, who always urged us to question the conventional wisdom.

1 e.g. Cato, Agr. Praef. 2-4; Varro, Rust. 2 Praef. I-2; 3.2.4; Cic., Off. I.I5I; cf. Columella, Rust. I Praef. Io.

2 e.g. I. Shatzman, Senatorial Wealth and Roman Politics (1975), 50, but cf. 73-4; K. Hopkins, Conquerors and Slaves (I978), 48; cf. R. Duncan-Jones, The Economy of the Roman Empire. Quantitative Studies ${ }^{2}$ (I982), I9; more guardedly, W. V. Harris, War and Imperialism in Republican Rome 327-70 B.C. (I979), 79-80; J. D'Arms, Commerce and Social Standing in Ancient Rome (I98I), 36.

${ }^{3}$ Hopkins, op. cit. (n. 2), 49.

${ }^{4}$ Hopkins, op. cit. (n. 2), 54: 'It was the shortage of alternative investments and the high status of land-holding which above all induced men to invest capital in land. Among senators there was an additional pressure. The opportunity to profit hugely from empire occurred infrequently. Many senators had only one or two chances in a life-time to hold government posts in the provinces, and that in a junior capacity ... The bulk of senators, therefore, could not be sure that either they or their sons would have another opportunity to make money out of high office. The senators who were successful therefore felt constrained to make their pile and invest it in land. It might have to support the family for generations.'
} 
slaves who tilled the fields that they had once worked, consumers whose need for sustenance underwrote the prosperity and political ascendancy of the Republican élite. ${ }^{5}$

Despite this model's economy and explanatory power, however, criticisms levelled against one or another of its elements have over the last thirty-five years gradually undermined its foundations. ${ }^{6}$ Still, the central premise upon which the theory rests, namely that the Republican political élite's need to transform occasional windfalls from spoils or the plundering of provincials into a dependable, long-term source of income would inevitably have led them to expand their estates, remains untouched by these criticisms. Even if slavebased plantations were not as widespread as earlier scholars imagined and even if Italy's small farms were not in as dire straits as once thought, it would seem self-evident that a growing need for food among Italy's growing urban population during the second and first centuries B.C., coupled with the aristocrats' desire to secure the increasingly large, steady cash flows they required to sustain the life-style and expenditures expected of members of the Republic's political class, would have led them to buy more land. ${ }^{7}$ Yet the question has only rarely been posed: how much money could senators expect to make from farming in the middle and late Republic?

Attempts to gauge the profitability of commercial agriculture in this period have generally taken one of two forms. In the first, scholars have sought to calculate the returns from a vineyard or other type of farm of a given size and worked by a given number of slaves based on estimates of the costs of land, the upkeep of the establishment, the price of wine or oil, and so forth. So, for example, Cavaignac has reckoned that the olive plantation of 240 ingera that Cato describes in De agricultura io would have returned 8,000 denarii annually in gross profit, while Tenney Frank estimates the gross profit from a similarly-sized orchard at HS 50,000 (= I2,500 denarii). ${ }^{8}$ Shatzman reckons that Cato's Ioo ingera vineyard would have netted HS I60,000 in annual income, and other scholars have employed similar methods to reach other results. ${ }^{9}$ Hopkins, however, eschews that

\footnotetext{
5 Hopkins, op. cit. (n. 2), I-98, especially II-I5, is the now classic formulation of the scheme, cf. I04-5. See also P. A. Brunt, Italian Manpower 225 B.C.-A.D. I4 (I97I), I55; idem, The Fall of the Roman Republic and Related Essays (I988), 73.

${ }^{6}$ On the lack of evidence for the establishment of plantation agriculture before the early first century B.C., see e.g. M. Frederiksen, 'The contribution of archaeology to the agrarian problem in the Gracchan period', Dial. di Arch. 4-5 (I970-7I), 330-57; J. K. Evans, 'Plebs rustica. The peasantry of classical Italy', AJAH 5 (I980), I9-47; idem, War, Women and Children in Ancient Rome (I99I), I08-I3; S. Dyson, Community and Society in Roman Italy (I992), 23-55; T. Potter, The Changing Landscape of South Etruria (I979), I25; idem, Roman Italy (I987), II5-I6; M. Torelli, Tota Italia. Essays in the Cultural Formation of Roman Italy (1999), 5-8. For the importance of neighbouring small farmers to such enterprises: D. Rathbone, 'The development of agriculture in the "ager Cosanus" during the Roman Republic: problems of evidence and interpretation', JRS 7I (I98I), I2-I5. W. Jongman, 'Slavery and the growth of Rome. The transformation of Italy in the second and first centuries BCE', in C. Edwards and G. Woolf (eds), Rome the Cosmopolis (2003), II2-I6, shows that even at its height, the extent of plantation agriculture in Italy would have been far more limited that usually thought. This finding has led to a radical revision downward of the numbers of slaves assumed in the population: W. Scheidel, 'Human mobility in Roman Italy, 2: the slave population', JRS 95 (2005), 64-7I; L. de Ligt, 'Poverty and demography: the case of the Gracchan land reforms', Mnemosyne 57 (2004), 725-57, countering the claims of J. Beloch, Bevölkerung der griechisch-römischen Welt (I886), 4I8; Brunt, op. cit. (n. 5, I97I), I24; and Hopkins, op. cit. (n. 2), 8 n. I4. On the supposedly deleterious effects of Roman warfare on small farmers and the economic viability of their farms, see J. Rich, 'The supposed manpower shortage of the later second century B.C.', Historia 32 (I983), 3I6-2I; N. Rosenstein, Rome at War. Farms, Families, and Death in the Middle Republic (2004), 26-106.

7 Here and throughout this paper, the term 'aristocrats' is used to describe members of the Senate and their immediate kin.

${ }^{8}$ E. Cavaignac, Population et capital dans le monde méditerranéen antique (1923), 97-100; T. Frank, Economic Survey of Ancient Rome, Vol. I (I933), I70-I, followed by Shatzman, op. cit. (n. 2), 47-8 and C. Yeo, 'The economics of Roman and American slavery', Finazarchiv I3 (I952), 475. Cf. R. Billiard, La Vigne dans l'antiquité (I9I3), II2-47.

9 Cato, Agr. II; Shatzman, op. cit. (n. 2), 47-8. Other calculations: T. Frank, An Economic Survey of Ancient Rome, Vol. 5 (I940), I49-53, followed by K. D. White, Roman Farming (I979), 268-9 and Yeo, op. cit. (n. 8), 475-6; Duncan-Jones, op. cit. (n. 2), 33-59; Rathbone, op. cit. (n. 6), I2-I 5, cf. N. Morley, Metropolis and Hinterland. The City of Rome and the Italian Economy, 200 B.C.-A.D. 200 (I996), I24-6.
} 
approach and argues simply that 'if Roman nobles' and knights' incomes came in large measure from rents, or from the direct exploitation of land, then the areas of good land which a rich man controlled must have been large ... If, on average, Roman senators got only 60,000 HS a year from agricultural rents (this is low; it was only ten per cent of Cicero's very rich man's income), and if rents equalled thirty per cent of the gross crop (which is high), then at a conventional price for wheat, it works out that 600 senators together owned land sufficient to maintain 200,000 peasant families (i.e. 800,000 men, women and children) at the level of minimum subsistence'. ${ }^{10}$ Certainly such an estimate seems eminently plausible in light of the remark by Cicero to which Hopkins refers, a comparison of the income of a rich man with someone very rich: 'He makes HS 600,000 from his estates, I make HS roo,ooo from mine. ${ }^{11}$

This paper will argue, however, that efforts to ascertain the profitability of commercial agriculture overlook a critical variable, namely the size of the demand for wine, oil, and wheat. Scholars have simply assumed that the market could absorb everything growers could produce, assuring aristocratic landowners an ample income from their estates. ${ }^{12}$ But even the most generous estimates of the demand for wine, oil, and wheat strongly suggest that commercial agriculture would not have promised very attractive returns. Profits in most cases were small and insufficient to support many aristocrats in lavish style. This hypothesis makes good sense out of some of our best evidence for aristocratic attitudes towards money and farming in the middle and late Republic. More importantly, it allows us to take a somewhat broader view of investment and profit and to see that rather different sorts of investment strategies could pay bigger long-term dividends to a senator and his descendants.

II DEMAND AND SUPPLY: THE MIDDLE REPUBLIC

Most Romans and Italians lived on small, family-run farms. They grew the bulk of the food they consumed and obtained the rest through small-scale, local exchange. Large-scale producers of agricultural commodities consequently would have found the great majority of their customers among Italy's non-agricultural, urban population. ${ }^{13}$ Therefore any analysis of this market must begin with an attempt to gauge its size. Estimates of Rome's population in the mid-third century range from 90,000 to 187,500 , while Morley puts the number at around 200,000 for $c .200$ B.C. ${ }^{14}$ These figures may be taken to represent reasonable bounds of probability - it is difficult to imagine that Rome in the mid-third century was much larger than 200,000 if the total citizen population in 225 B.C. was around a million, while anything below 90,000 would seem surprisingly small for a city that, at least

\footnotetext{
${ }^{10}$ Hopkins, op. cit. (n. 2), 55-6.

11 Cic., Parad. 49: 'Capit ille ex suis praediis sescena sestertia, ego centena ex meis'; cf. Hopkins, op. cit. (n. 2), 50.

12 e.g. Hopkins, op. cit. (n. 2), I07: 'An increase in productivity would have been useless without its reciprocal: the creation of a market. Land-owners needed to sell the newly created surplus so that they could make a return on their investment in land and slaves. The peasants who migrated to Rome (and other Italian towns) and the new urban slaves together provided this market.'

13 On the relative importance of Italian markets, and especially Rome, in comparison to exports, especially of wine, to Gaul, see Morley, op. cit. (n. 9), I I2-I4, and also below; on the focus of large-scale commercial farmers on urban markets rather than local nundinae, idem, 'Markets, marketing, and the Roman elite', in E. Lo Cascio (ed.), Mercati permanenti e mercati periodici nel mondo romano (2000), 2I3-2I.

14 C. Starr, Beginnings of Imperial Rome: Rome in the Mid-Republic (I980), I5-I9, followed by T. Cornell, Beginnings of Rome: Italy and Rome from the Bronze Age to the Punic Wars (c. I000-264 BC) (I995), 385; Brunt, op. cit. (n. 5, I97I), 384 (c. 270 B.c.); Morley, op. cit. (n. 9), 39; cf. W. Scheidel, 'Human mobility in Roman Italy, I: the free population', JRS 94 (2004), I4, who estimates the freeborn population of Rome at I50,000 C. 200 B.C. and 375,000 a century later.
} 
by the opening of the Hannibalic War, controlled nearly the whole of the peninsula. ${ }^{15}$ By the end of the middle Republic, around I33 B.C., Rome had grown enormously. Brunt takes the construction of the Aqua Marcia in I44 B.C. as an indication that Rome's population had at least doubled in the interval to around 375,000. Morley puts the total even higher at half a million. ${ }^{16}$

Establishing the number of potential urban consumers in the rest of Italy is more difficult, in part because there are few estimates for the populations of other Italian cities during the third and second centuries B.C. ${ }^{17}$ Tarentum, for example, is thought to have had a population of around IIO,000-150,000 during the fourth century but to have declined significantly in the third, following its defeat by Rome, until it numbered around 60,000 at the time of the Second Punic War. Naples might have contained between 7,000 and 8,000 residents in the late fourth century B.C. ${ }^{18}$ The populations of Arpi and Canosa are each put at about 30,000 in the third century B.C. and Herdonia might have had roughly the same number.$^{19}$ Equally problematic, however, is the extent to which members of the middle Republic's political class would have had access to these markets. Capua, Neapolis, and the other Campanian towns, as well as those of Latium, would have been easily accessible to growers with holdings in central Italy, but the cities of Magna Graecia, Apulia and elsewhere would probably have been largely out of reach and supplied from their own hinterlands. For the late Republic, Hopkins proposed that Italy's urban population was about I,900,000, of whom between 800,000 and a million resided in Rome itself. ${ }^{20}$ This was at the end of a period of dramatic urban growth in the first century B.C.; the peninsula was far less urbanized in the third and second centuries. ${ }^{21}$ Let us suppose, however, that the market to which third- and second-century Roman aristocrats might have had access equalled that of Rome itself, so that the total number of potential consumers ranges from a low of I 80,000 to a million. The implications of a smaller market will be taken up below.

What then was the size of the demand for food that these populations might have represented? Jongman reckons the average per capita consumption of wine at roo litres per year, while Morley places it higher, at 160 litres. ${ }^{22}$ Amouretti offers estimates of the

\footnotetext{
15 See E. Lo Cascio, 'The size of the Roman population: Beloch and the meaning of the Augustan census figures', JRS 84 (I994), 39, for ratios of rural to urban dwellers in other pre-industrial societies.

16 Brunt, op. cit. (n. 5, I97I), 384; Morley, op. cit. (n. 9), 39, cf. II3; cf. G. Rickman, The Corn Supply of Ancient Rome (I980), II. However, Garnsey, Gallant and Rathbone regard these figures as much too high and suggest a population of only 250,000 for Rome in the mid-second century B.C.: P. Garnsey, T. Gallant and D. Rathbone, 'Thessaly and the grain supply of Rome during the second century B.C.', JRS 74 (I984), 40.

${ }_{17}$ For estimates of town populations during the Principate: Duncan-Jones, op. cit. (n. 2), 266-77.

18 Tarentum: M. Pani, 'Economia e societá in età romana', in G. Musca (ed.), Storia della Puglia, Vol. I (I978), I00. Naples: P. Arthur, Naples, from Roman Town to City State: An Archaeological Perspective (2002), 5-6.

19 Arpi and Canosa: Pani, op. cit. (n. I8), Ioo. Herdonia: J. Mertens and B. Volpes, Herdonia. Un itinerario storicoarcheologico (1999), 24, estimate the population at 7,000-I0,000 in the late Republic, although perhaps much reduced as a consequence of its vicissitudes during the war with Hannibal: Livy 27.2.I4-I5. See also G. Kron, 'The Augustan census figures and the population of Italy', Ath. 93 (2005), 488-9 for other Italian urban population estimates.

${ }^{20}$ Hopkins, op. cit. (n. 2), 68-9, 96-8; cf. R. Witcher, 'The extended metropolis: Urbs, suburbium and population', $J R A$ I8 (2005), I26, who notes that 'the current consensus is $c .0 .75$ million inhabitants'.

${ }^{21}$ E. Gabba, 'Urbanizzazione e rinnovamenti urbanistici nell'Italia centro-meridionale del I Sec. a.C.', SCO 2I (I972), 73-I I2; idem, 'Considerazaioni politiche ed economiche sullo sviluppo urbano in Italia nei secoli II e I a.C.', in P. Zanker (ed.), Hellenismus in Mittelitalien: Kolloquium in Göttingen vom 5. bis 9. Juni I974 (I976), 3I 5-26.

22 W. Jongman, The Economy and Society of Pompeii (I988), I32-3; idem, op. cit. (n. 6), II 3 -I4, based on comparative evidence from early modern cities in Spain and France, cf. Hopkins, op. cit. (n. 2), 3 n. 6. Morley, op. cit. (n. 9), II3, follows N. Purcell, 'Wine and wealth in ancient Italy', JRS 75 (I985), I3, who bases his estimate on Cato's rations for his slaves $(A g r .57)$, assumes half that amount for women and children, and estimates that they constituted two-thirds of the population.
} 
average annual per capita consumption of olive oil that fall between 20 and 30 litres. $^{23}$ Wheat consumption in the view of Hopkins and others averaged about $200 \mathrm{~kg}$ per person per year; Rickman, however, follows Beloch in putting the figure higher, at $266 \mathrm{~kg} .{ }^{24} \mathrm{On}$ the basis of these figures, the wine consumption of I 80,000 urban dwellers in the mid-third century would have been, at a minimum, I8 million litres a year, plus 3.6 million litres of oil, and around 36 million $\mathrm{kg}$ of wheat. That demand would have increased by I 33 B.C. to a maximum of 160 million litres of wine, 30 million litres of oil, and 266 million $\mathrm{kg}$ of wheat. These are impressive numbers, and at first blush they seem to bear out the usual assumption that the urban markets of Italy could have provided the senatorial class with ample profits from the sale of the products grown on their estates.

However, plenty of other wealthy men apart from senators might have hoped to draw a comfortable livelihood from market-agriculture, and for once the sources offer some indication of their numbers. Polybius, drawing on Fabius Pictor, reports that in 225 B.C. 23,000 Romans were rich enough to qualify for cavalry service. ${ }^{25}$ In concrete terms cavalry service meant ownership of (or the means to purchase) the three horses and two servants that accompanied a citizen cavalryman on campaign. ${ }^{26}$ Members of the Republic's cavalry class were clearly men of substance, and we can expect that they, too, would have looked upon Italy's urban dwellers as customers for the products of their farms. Senators, in other words, would have had plenty of potential competitors in the urban marketplace. Yet even these two categories would not necessarily have encompassed all possible sellers. Livy reports that in 2 I 4 B.C. the Senate faced a severe shortage of oarsmen for a newly launched fleet of a hundred ships. It therefore decreed that citizens should furnish slaves to man them according to each citizen's economic status. Those who had been rated by the censors of 220 B.C. at 50,000 asses (or had attained this level in the intervening years) were to supply one slave and six months' pay; those worth Io०,०o० asses provided three sailors and a year's pay; citizens at 300,000 asses were to furnish five slaves; those worth a million,

\footnotetext{
23 M.-C. Amouretti, Le pain et l'huile dans la Grèce antique: de l'araire au moulin (I986), I8I-3, I95-6, for the urban populations of Archaic and Classical Greece, accepted as reasonable estimates for Italy by D. Mattingly, 'Oil for export? A comparison of Libyan, Spanish and Tunisian olive oil production in the Roman empire', JRA I (I988) 34; idem, 'Olea Mediterranea', JRA I (I988), I59.

${ }_{24}$ Hopkins, op. cit. (n. 2), 97-8, who, however, regards this figure as somewhat high, although at op. cit. (n. 2), 3 n. 6 he considers $160 \mathrm{~kg}$ per year somewhat low. He is followed by P. Garnsey, 'Grain for Rome', in P. Garnsey, K. Hopkins and C. R. Whittaker (eds), Trade in the Ancient Economy (I983), II8, Morley, op. cit. (n. 9), 35, and Jongman, op. cit. (n. 6), II5; cf. Garnsey, Gallant and Rathbone, op. cit. (n. I6), 40. Rickman, op. cit. (n. I6), Io and Beloch, op. cit. (n. 6), 4I6-I7 estimate 40 modii per person per year, which at $6.65 \mathrm{~kg} /$ modius (below n. 67) works out to $266 \mathrm{~kg}$; so, too, K. Harl, Coinage in the Roman Economy 300 B.C. to A.D. 700 (I996), 27I. An intermediate figure of $237 \mathrm{~kg}$ per person per year in G. Aldrete and D. Mattingly, 'Feeding the city: the organization, operation, and scale of the supply system for Rome', in D. Potter and D. Mattingly (eds), Life, Death, and Entertainment in the Roman Empire (1999), I93.

25 Polyb. 2.24.I4, cf. Brunt, op. cit. (n. 5, I97I), 44-5; D. Baronowski, 'Roman military forces in 225 B.C. (Polybius 2.23-4)', Historia 42 (I993), I8I-202. Pictor as the source for Polybius' figures: Eutr. 3.5; Oros. 4.I3.6. Scheidel raises significant questions about the overall reliability of Polybius' figures, but seems to accept that Polybius' Roman totals were accurate: op. cit. (n. I4), 4. The figure of 23,000 includes the equites equo publico, but since there were only $\mathrm{I}, 800$ of these, subtracting them from Polybius' figure would make little difference to the point being made here.

${ }_{26}$ These figures are based on the rations issued to citizen cavalrymen given in Polyb. 6.39.I3, cf. F. Walbank, A Historical Commentary on Polybius, Vol. 2 (1967), 648; P. Erdkamp, Hunger and the Sword. Warfare and Food Supply in Roman Republican Warfare (264-30 B.C.) (I998), 28; J. McCall, The Cavalry of the Roman Republic. Cavalry Combat and Elite Reputations in the Middle and Late Republic (2002), 7. It seems as though even the equites equo publico were furnished with only a single horse at state expense and had to supply their additional mounts out of their own purses.
} 
seven; and senators, eight. ${ }^{27}$ This remarkable passage affords a unique glimpse into the distribution of slave-holding among the Roman population around the turn of the third century B.C., for the arresting feature of the categories the Senate defined is that the first two correspond to the third and first census classes. ${ }^{28}$ This is worth emphasizing: the patres evidently expected that men squarely in the middle of the Republic's socio-economic hierarchy would own (or be able to purchase) at least one adult male slave, while those in the first census class could be called upon to contribute three. ${ }^{29}$ And they may well have owned more, since it is questionable whether the patres would have required any slaveowner to give up his entire servile work-force to the war-effort. ${ }^{30}$ While no figure survives for an official senatorial census in the middle Republic, one may suspect that the million asses cited in this passage represented something very like a de facto threshold for membership of the Senate. ${ }^{31}$ The additional slave the senators required of themselves beyond the seven expected from those rated at a million asses arose from a kind of noblesse oblige and simply served to mark the senators' higher social status rather than representing any significant economic superiority over the millionaires. ${ }^{32}$ The figure of 300,000 asses corresponds to no known census rank or other category within the Roman hierarchy, but again one may suspect that this represented the amount that qualified a citizen for service in the

${ }^{27}$ Livy 24.II.7-8. That these sailors were slaves emerges clearly from 24.II.9: 'nautae armati instructique ab dominis', and from Livy 26.35.5. Cf. J. H. Thiel, Studies in the History of Roman Sea-Power in Republican Times (I946), 77; Brunt, op. cit. (n. 5, I97I), 65. H. Mattingly, 'The property qualifications of the Roman classes', JRS 27 (I937), I03-4, followed by J. E. A. Crake, Archival Material in Livy, Ph.D. dissertation, Johns Hopkins University (I939), 236-7, argues that these sums cannot represent sextantal asses since the retariffing of the as from the libral to the sextantal standard had not yet taken place. Therefore, the sums represent libral asses and those who possessed these very high levels of wealth were all members of the first census class alone. However, D. Rathbone, 'The census qualifications of the assidui and the prima classis', in H. Sancisi-Weerdenberg et al., De Agricultura: in Memoriam Pieter Willem de Neeve (1945-I990) (I993), I33-4, and E. Lo Cascio, 'Ancora sui censi minimi delle classi cinque «Serviane»', Ath. n.s. 76 (I988), 283-4, both assume plausibly that Livy or his source understood that the as had been reduced from a libral to a sextantal standard between this episode and the time he wrote and so simply translated sums from the former to the latter in order to make them comprehensible to his readers. Both Rathbone, op. cit., I23-5, especially I47-8, and Lo Cascio, op. cit., 289, 299-300, following a suggestion by Rich, op. cit. (n. 6), 3I4, further argue that the thresholds for the census classes were multiplied by ten around 2 I 2 B.C. in connection with the currency reform that took place at that time, in order to compensate for the dramatic lowering of the value of the as that the reform entailed. Otherwise, those thresholds would in real terms have dropped dramatically when the as was reduced from Io to 2 ounces; cf. M. Crawford, Coinage and Money under the Roman Republic. Italy \& the Mediterranean Economy (I985), I49-5I on the procedure used in translating census assessments in asses into sestertii when the sestertius was introduced as the standard unit of reckoning. Hence the sums of money Livy assigns to these and the other categories at 24.II.7-9 (and elsewhere) are anachronistic for 2I4 B.C., since they are expressed in sestantial ( 2 ounce) asses rather than in the libral (Io ounce) asses in use up to that point. The actual figures would therefore have been 5,000, 10,000, 30,000, and 100,000 libral asses.

${ }_{28}$ For that reason, it is highly likely that the figure of 75,000 asses and two slaves had dropped out of Livy's sources. For further discussion of the problems raised by this passage, see the Appendix.

${ }_{29}$ On the wealth of the first property class in the late Republic, see A. Yakobson, Elections and Electioneering in Rome: A Study in the Political System of the Late Republic (1999), 43-8.

30 Although slave-owners' complaints in 210 B.C. might suggest otherwise: Livy $26.35 \cdot 5-6$.

31 C. Nicolet, L'Ordre equestre à l'époque républicaine (3I2-43 av. J.-C.), Vol. I (I966), 64-8, followed by T. P. Wiseman, New Men in the Roman Senate, I39 BC-AD I4 (I97I), 66, identifies this figure as the minimum census required for enrolment among the equites equo publico, on the basis of its equivalent in sesterces, 400,000, which was unquestionably the equestrian census in the late Republic and early Empire: Nicolet, op. cit., 55-62. Hence for Nicolet those in this group in 2I4 B.C. were the equites equo publico: op. cit., $63-8$. On the question of whether the term equites applied only to those enrolled in the eighteen equestrian centuries or included also those not enrolled but who met the financial qualification, see T. P. Wiseman, "The definition of "eques romanus" in the late Republic and early Empire', Historia I9 (I970), 67-83. However, Rathbone argues, op. cit. (n. 27), I49 n. 25 , that since the equestrian census is only ever expressed in sesterces, it is unlikely that there was any formal equestrian census prior to the introduction of that unit of currency $c$. I 4 O B.C., and probably only $c$. I29 B.C. at the time of the plebiscitum equorum reddendorum; cf. P. Marchetti, Histoire économique et monétaire de la deuxième guerre punique (I978), 2II-I8. Shatzman, op. cit. (n. 2), 243, assumes the figure of one million asses given by Livy at 24.II.7-8 represents the senatorial census.

32 So Wiseman, op. cit. (n. 3I, I97I), 66. 
cavalry but not for the public horse. ${ }^{33}$ Even if that proves not to have been the case however, we would have to assume that as a rule citizens who provided their own mounts for cavalry service owned more than the three slaves of citizens of the first class, since the cavalrymen were an élite category within the first census class, chosen on the basis of their greater wealth.

This passage therefore reveals a surprisingly broad distribution of slave-ownership within middle Republican society, extending from the very top of the socio-economic pyramid to well within its middle reaches. While such widespread slave-ownership may be unexpected, the situation is not unparalleled. In the southern states of the antebellum United States, about a quarter of all white families held slaves in I860; in the preceding forty years the proportion of slave-owning families had risen as high as one third. However, somewhat less than 50 per cent of these families owned fewer than five slaves, 72 per cent fewer than ten, and 88 per cent fewer than twenty. Although the great majority of slaves were the possessions of owners of large plantations, 'the median slaveholding rarely strayed far from four to six bondsmen per master'. ${ }^{34}$ There is no reason a priori therefore to reject as inherently improbable the conclusion implied by the figures in the decree of 2I4 B.C., namely that slave-ownership was typical among citizens in the top three census classes as well as among those at the apex of the Republic's economic hierarchy. Consequently, the universe of potential sellers in the urban food marts of the ager Romanus and elsewhere is likely to have been much larger than simply the political élite. For while the product of the labour of a single male slave might have been consumed by his owner simply as leisure - the slave doing some or all of the agricultural work his master would otherwise have had to perform - the labour of three or more male slaves suggests a productive potential well beyond the immediate consumption needs of a slave-owning family. ${ }^{35}$

The archaeological evidence for the production of wine, oil, and other agricultural commodities in the countryside during the middle Republic points in a similar direction. There is now a general consensus that the villa in its classic form - containing not only luxurious quarters for its owners but also evidence of the 'slave mode of production' - is a development of the early first century B.C. For third- and second-century Italy excavation has revealed two very different sorts of rural establishments: a few grand residences, such as the auditorium site near Rome, whose origins stretch back to the fifth century or earlier, and a number of what are termed 'hellenistic farmsteads'. ${ }^{36}$ The farmhouses of the latter tend to be much smaller, around $500 \mathrm{~m}^{2}$, and most importantly show clear evidence of the production of an agricultural surplus for the market. So for example Site II on the Via Gabina in its earliest phase (IA) dates to the early third century B.C. By the mid-third

\footnotetext{
33 Cavalrymen who were not equites equo publico were selected by the censors on the basis of their wealth and their names entered on a list separate from that containing the names of those who would serve on foot: Polyb. 6.20.9, cf. McCall, op. cit. (n. 26), 3-5. This list of equites equo suo is clearly the basis for Fabius Pictor's statement that Rome's total cavalry force numbered 23,000 in 225 B.C.: above n. 25 . Consequently, there had to be some sum of money that allowed the censors to judge whether or not a citizen's wealth qualified him for cavalry service. However, this sum may never have been formally codified in law and may have varied from censorship to censorship. Cf. E. Gabba, Republican Rome. The Army and the Allies (1976), 55; M. Gelzer, Kleine Schriften, Vol. I (I96I), 224-5. Nicolet, op. cit. (n. 3I), 65, suggests the category of 300,000 asses might have been invented for the occasion, but this is unlikely in view of the correspondence between the first two sums named in the passage and the third and first census categories and his own claims that the figure of one million asses was the census equester.

${ }^{34}$ K. Stampp, The Peculiar Institution. Slavery in the Ante-Bellum South (1956), 29-3I; J. Oakes, The Ruling Race. A History of American Slaveholders (I982), 39-40, quotation from p. 39.

35 Although Cato worked in the fields alongside his slaves, the fact that Cato's neighbour, Valerius Flaccus, was amazed by this practice suggests that this was unusual among slave-owners: Plut., Cato Mai. 3.I-2.

36 Torelli, op. cit. (n. 6), 5-8; N. Terrenato, 'The auditorium site in Rome and the origins of the villa', JRA I4 (200I), 2I-4. The villa at Settefinestre is the prototypical example of a 'classical villa': A. Carandini and A. Ricci (eds), Settefinestre (I985). On the 'slave mode of production' generally: A. Giardina and A. Schiavone (eds), Società romana e produzione schiavistica (I98I, 3 vols).
} 
century (Phase IB) the excavators report that 'a channelled platform, probably a pressing floor for olives or grapes, perhaps both, was built in one of the rooms of the western arm' of the building. The cultivation of vines seems confirmed by an iron billhook uncovered in this same general area. The excavators reckon the fields that surrounded the farmstead at about I6 ingera (although the possibility that the farm's occupants worked other land that was not contiguous cannot be ruled out), and note the presence of First-style Pompeian wall-stucco, denoting a certain degree of luxury. ${ }^{37}$ The money to pay for that luxury in all probability came from the sale of wine, oil, or other agricultural commodities in Rome, only I4 km away. Likewise, the earliest phase of the Villa Sambuco in Western Etruria dates to the first half of the second century в.c. Although the building was modest in size, only about $380 \mathrm{~m}^{2}$, it contained four large storerooms in which a large number of dolia had been set into the ground. The excavators conclude that, 'It is evident from the size of the storage rooms that this farm was producing crops for sale elsewhere, for they held considerably more than the people on the farm could consume'. They suggest that the farm was run by a vilicus for an absentee owner, since no rooms that seem suitable for an owner have been found. Since the building contained a second storey, however, it is possible that the owner's apartments were located there. ${ }^{38}$ Other small farmsteads from this period with evidence suggesting the production of a surplus for local urban markets include the Giardino Vecchio and Posta Crusta sites. ${ }^{39}$

The archaeological evidence, of course, does not tell us who owned these farms. It is entirely possible that each was but one of many similar establishments owned by a wealthy senator. Still, the point they make is that smaller commercial farms like these were able to compete as sellers in the urban marketplaces of the middle Republic. Whatever competition they faced there from larger establishments had not driven them out of business. And smaller farms like these that produced on a relatively modest scale would have been well within the financial reach of middling members of the Roman socio-economic hierarchy, precisely the sorts of men who owned a few slaves and whose existence Livy's description of the naval draft of 2I4 B.C. reveals.

This conclusion allows us to form some idea of the market conditions for commercial agriculture in the middle Republic and to estimate the size of its supply-side, wherein Roman senators might have competed to sell their wares. Table I attempts to describe the relationships between demand and supply for the most commonly marketed commodities produced on large farms. It shows what the minimum demand for wine, oil, and wheat would have been at the urban population levels discussed earlier, how that demand would have been divided among 23,300 producers if each one obtained an equal share of the market, and finally, how much land each producer would have had to cultivate in order to meet his portion of this demand. The figure of 23,300 producers has been chosen somewhat arbitrarily; it is simply 300 senators plus the 23,000 cavalrymen of 225 B.C. Some of these 23,000 men would still have been under their fathers' potestas, so that the number of households producing crops for market would have been somewhat smaller than the number of individuals qualified for cavalry service, since a father's census rating would

\footnotetext{
37 W. Widrig, 'Land use at the via Gabina villas', in E. B. MacDougall (ed.), Ancient Roman Villa Gardens (I987), 227-5I, quotation from p. 25I; idem, 'Two sites on the ancient via Gabina', in K. Painter (ed.), Roman Villas in Italy. Recent Excavations and Research (1980), I20-3.

38 C. Östenberg, 'Luni and the villa Sambuco', in A. Boëthius et al., Etruscan Culture, Land and People (I962), 3I 3 -20; E. Berggren, 'A new approach to the closing centuries of Etruscan history: a team-work project', Arctos 5 (I967), 29-43.

39 Giardino Vecchio: A. Carandini, La romanizzazione dell'Etruria: il territorio di Vulci (I985), I06-7; Posta Crusta: G. De Boe, 'Villa romana in località "Posta Crusta". Rapporto provissorio sulle campagne de scavo I $972 \mathrm{e}$ I973’, NSc 39 (I975), 52I-3; G. Volpe, La Daunia nell'età della romanizzazione. Paesaggio agrario, produzione, scambi (I990), IIO-II.
} 
TABLE I

WINE

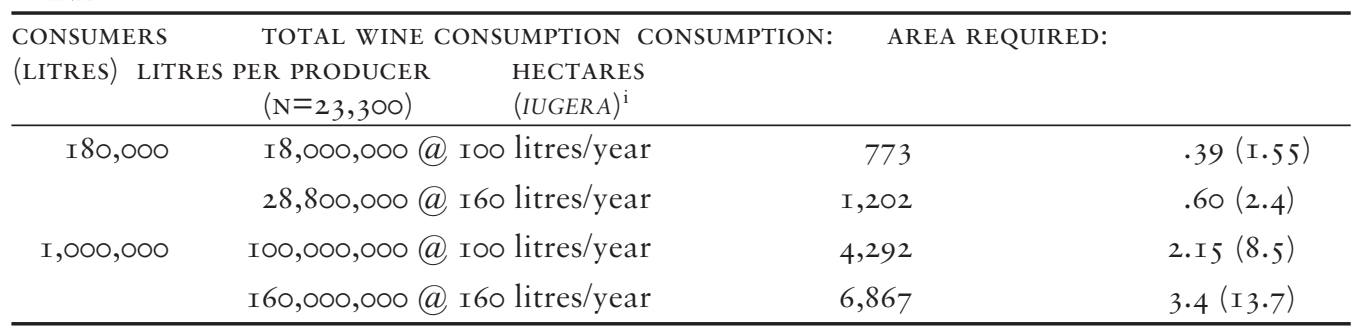

OIL

\begin{tabular}{|c|c|c|c|}
\hline CONSUMERS & $\begin{array}{c}\text { TOTAL OLIVE OIL } \\
\text { CONSUMPTION (LITRES) }\end{array}$ & $\begin{array}{c}\text { CONSUMPTION: } \\
\text { LITRES PER PRODUCER } \\
(\mathrm{N}=\mathbf{2 3}, 300)\end{array}$ & $\begin{array}{l}\text { AREA REQUIRED: } \\
\text { HECTARES } \\
(\text { IUGERA })^{\mathrm{ii}}\end{array}$ \\
\hline \multirow[t]{2}{*}{ I 80,000} & 3,600,000@20 litres/year & I 55 & $.35(\mathrm{I} .4)$ \\
\hline & 5,400,000@30 litres/year & 232 & $.53(2.12)$ \\
\hline \multirow[t]{2}{*}{$\mathrm{I}, \infty 00, \infty 00$} & 20,000,000@20 litres/year & 858 & I.95 (7.74) \\
\hline & 30,000,000@30 litres/year & $\mathrm{I}, 288$ & $2.93($ II.72) \\
\hline
\end{tabular}

WHEAT

\begin{tabular}{|c|c|c|c|}
\hline CONSUMERS & $\begin{array}{l}\text { WHEAT CONSUMPTION } \\
\text { (KILOS) }\end{array}$ & $\begin{array}{c}\text { CONSUMPTION: } \\
\text { KILOS PER PRODUCER } \\
(\mathrm{N}=23,300)\end{array}$ & $\begin{array}{l}\text { AREA REQUIRED: } \\
\text { HECTARES } \\
(\text { IUGERA })^{\mathrm{iii}}\end{array}$ \\
\hline \multirow[t]{2}{*}{ I 80,000} & 36,000,000@200 kg. per year & $\mathrm{I}, 545$ & $3.9(15.5)$ \\
\hline & 47,880,000@266 kg. per year & 2055 & $5 \cdot I(2 I)$ \\
\hline \multirow[t]{2}{*}{ I, $, 0 \circ,, 00$} & 200,000,000@200kg. per year & 8,584 & $2 \mathrm{I} .5(85.3)$ \\
\hline & 266,000,000@266kg.per year & II, 4 I 6 & 29.5 (I I 4$)$ \\
\hline
\end{tabular}

i This calculation is based on an average yield of wine per hectare of 2,000 litres: Duncan-Jones, op. cit. (n. 2), 40, 45, followed by Rathbone, op. cit. (n. 6), I2, and Jongman, op. cit. (n. 22), I32, cf. idem, op. cit. (n. 6), II4. However, Purcell, op. cit. (n. 22), I3 argues that Columella's minimum yield of 4,500 litres per hectare is not improbable, and if this estimate is preferred, the amounts of land required would shrink dramatically.

ii Based on an estimated yield of 440 litres per hectare.

iii Based on an average net yield of $400 \mathrm{~kg}$ per hectare: Jongman, op. cit. (n. 6), I I 5 ; cf. Rosenstein, op. cit. (n. 6), $67-8$ for a somewhat more pessimistic estimate of net yield.

determine not only his own military obligations but his sons' as well. ${ }^{40}$ Still, this figure seems a defensible and even somewhat conservative estimate of the number of Romans who would have pursued commercial agriculture if citizens in the first census class typically owned three or more slaves. It is also important to bear in mind that this estimate takes no account of Latin or Italian producers who might have sold their crops in Rome or elsewhere. Farmers in Etruria in particular would have been well positioned to bring

\footnotetext{
40 Roman men typically married in their late twenties in this period, and so between 50 and 70 per cent of men between the ages of eighteen and thirty who were qualified for cavalry service would have lost their fathers: Rosenstein, op. cit. (n. 6), 82-4; R. Saller, Patriarchy, Property and Death in the Roman Family (I994), tables 3.I.e and 3.2.e. Of those fathers still living, a considerable number will have been older than forty-six and so legally exempt from military service and therefore not counted among those qualified for cavalry service.
} 
their crops to Roman markets, as would grain-producers in Sicily or Sardinia. ${ }^{41}$ And finally, Table I assumes that while the urban population grew between the third and second centuries B.C., the number of potential producers remained constant, which is unlikely to have been the case. So there is little reason to regard the estimate of 23,300 as too high.

The striking feature of Table $\mathrm{I}$ is how small the average market share per producer is even at the highest estimate of consumers. Even at an urban population of a million, the average market share amounts to 6,867 litres of wine per producer, the product of about I4 ingera of vineyards, and I,288 litres of olive oil, which could be obtained from an orchard a little smaller than I2 iugera. Only the wheat requirements of a million consumers seem to provide a significantly larger average market share at about 8,600-II,400 $\mathrm{kg}$ per producer, requiring between 85 and I I 4 ingera to grow. Yet the wheat market is just where Roman producers might expect the most competition from non-Roman growers in Italy or abroad. Furthermore, a farm of 85 -II 4 ingera hardly qualifies as a vast estate. That amount of arable could be worked by as few as four slaves. ${ }^{42}$ Certainly, those who owned farms which could devote that much land to cash crops would scarcely have counted as grandees: at the foundation of the second-century colony at Aquileia, centurions received Ioo ingera apiece and equites I40; equites at Bononia obtained 70 ingera, while ordinary colonists got 50 ; and at Luna colonists were allotted $5 \mathrm{I} / 2$ ingera each. ${ }^{43}$

Table I also permits some tentative estimates of the gross profits that commercial agriculture might generate. We have almost no data on prices in the third or second centuries B.C., and the prices of agricultural commodities in all periods can fluctuate considerably. However, Cato's De agricultura contains one nugget of evidence on the price of olive oil in the mid-second century B.C.: HS 25 for 50 Roman pounds. At this price, the value of 3,600,000 litres of oil would have been HS 5,020,540, while 30,000,000 litres would be worth HS 4I,837,839. ${ }^{44}$ Again, while these might seem very considerable sums in the aggregate, apportioned among 23,300 producers they work out to about HS 2I5.5 (53.88 denarii) per producer in the first case and HS I,795.6 (449 denarii) in the second. For the sake of comparison, one may note Cato's claim, as recorded by Polybius, that around the middle of the second century a jar of Pontic salted fish cost 300 denarii (assuming that Polybius' drachma equals one denarius).$^{45}$ Moreover, it is not clear whether Cato's figure represents the retail price a purchaser would pay or the wholesale price a producer could expect to receive for his oil. If the former, then the wholesale price ought to have been significantly less. And in either case, the sums in question represent gross profits exclusive of costs. If the latter are figured in, the net profit will have been much smaller. ${ }^{46}$ Of course caution is called for when considering evidence like this. We have no way of knowing how Cato's price for oil compares to average prices during the second century, or in areas other than Campania, or the range of variations from the mean. But even if we assume that prices were normally double, triple, or even higher than those Cato gives, the sums that an individual producer might expect from selling oil do not appear to be very great.

\footnotetext{
41 On third- and second-century imports from Sicily and Sardinia, see Rickman, op. cit. (n. I6), 36-7, I04-7; P. Erdkamp, 'Feeding Rome or feeding Mars? A long-term approach to C. Gracchus' lex frumentaria', Ancient Society 30 (2000), 53-70.

42 Duncan-Jones, op. cit. (n. 2), 328.

43 Aquileia: Livy 40.34.2; Bononia: Livy 37.57.8; Luna: Livy 45.I3.5.

44 Cato, Agr. 22.3. One Roman pound is equal to about 323 grams (Duncan-Jones, op. cit. (n. 2), 369-70), so that 50 Roman pounds equals I6.I5 kg. I6.I5 kg/HS $25=0.646 \mathrm{~kg}$ per HS I, thus HS I $/ .646 \mathrm{~kg}=\mathrm{HS}$ I.548 per I $\mathrm{kg}$ of oil. I kg of oil $=$ approx. I.I I litres at a specific gravity of about $0.9 \mathrm{~kg} /$ litre (Jongman, op. cit. (n. 6), I I4). Therefore $3,600,000$ litres of oil / I.II = 3,243,243 kg. At HS I.548 per kg, the oil therefore has a value of HS 5,020,540. $30,000,000$ litres / I.II $=27,027,027 \mathrm{~kg}$ with a value of HS $4 \mathrm{I}, 837,839$.

${ }_{45}$ Polyb. 3I.25.5, cf. Diod. 3I.24, 37.3.5; F. Walbank, A Historical Commentary on Polybius Vol. 3 (I979), 500-I. For a summary of the controversy over the value of Polybius' drachma, see Crawford, op. cit. (n. 27 ), I46-7.

46 The main costs involve the amortization of the prices of land and slaves and perhaps the costs of temporary free labour. For various estimates of costs, see the works cited above in n. 9.
} 
It might be argued, however, that the high costs of the pressing equipment and storage facilities necessary to produce crops for market would have put the commercial production of wine and oil, at least, out of reach of all but the wealthiest investors. As usual, we have very little data on which to base a judgement. However, Cato also records the cost of an olive-press. One could be purchased near Suessa, transported, and assembled for a total of HS 629; a mill could also be bought at Pompeii, transported, and assembled for HS $724 .{ }^{47}$ And Cato offers a helpful point of comparison for judging what the cost of an olivemill might represent in real terms. Cato's specific complaint about the price of a jar of salted fish noted above was that at 300 drachmas it cost more than a ploughman, meaning that Cato reckoned the price of a skilled field-hand as less than HS I, 200. ${ }^{48}$ Frank, however, claims that Cato's estimate of the cost of a farm slave is rather low, 500 drachmas (or HS 2,000) being a more usual price. ${ }^{49}$ In other words, an olive-press of the sort Cato describes would have been well within the means of men who were able to buy several slaves. Cato gives no indication of the prices of the various other articles necessary to produce wine or oil - baskets, vats, tubs, shovels, tables, hoes, etc. - but these items are not likely to have come anywhere close to the cost of as sophisticated a piece of equipment as an olive-press. ${ }^{50}$ Certainly, the wine-press Cato describes is much less complex than an olive-mill and so presumably considerably less expensive. ${ }^{51}$

III DEMAND AND SUPPLY: THE LATE REPUBLIC

Market conditions in the late Republic are much more difficult to assess. The early first century B.C. saw Italy's urban population grow dramatically. As noted above, Hopkins estimated that by the end of the Republic the peninsula's non-agricultural, city residents numbered about I,900,000, while Morley put the total at 2,325,000 for the mid-first century A.D., and we may take these figures as setting reasonable bounds to the size of the urban market in the late Republic. ${ }^{52}$ However, we are much more poorly informed about the supply side, that is, the total number of potential producers. Certainly the senators, who numbered around 600 members after Sulla's reforms, must be counted among them along with the equites, who in economic terms constituted with the senators a single upper class, but we have no reliable figure for the size of the equestrian order before the age of Augustus, when Dionysius of Halicarnassus reports that as many as 5,000 equites took part in the transvectio. ${ }^{53}$ However, these men were the equites equo publico, formally enrolled in the eighteen equestrian centuries. The equestrian order in the larger sense of those who met the census qualification but were not included among those in the eighteen centuries was certainly much larger. ${ }^{54}$ It included men like the elder Sex. Roscius, owner

47 Cato, Agr. 22.3.

48 Polyb. 3I.25.5a [24.4].

49 Frank, op. cit. (n. 8), I95, based on the ransom price paid in the early second century for Roman prisoners-ofwar who had been sold into slavery in Greece: Plut., Flam. I3.4-5.

50 Cato, Agr. IO-I3.

51 Cato, Agr. I9.I-2.

52 Hopkins, op. cit. (n. 2), 68-9, 96-8; Morley, op. cit. (n. 9), I82. However, E. Lo Cascio, 'The population of Roman Italy in town and country', in J. Bintliff and K. Sbonias (eds), Reconstructing Past Population Trends in Mediterranean Europe (3000 BC-AD I800) (I999), I65-6, suggests a free urban population of as many as $3,500,000$ for the imperial period. An assessment of the implications of this estimate, which is based on Lo Cascio's general argument for a much higher population of Roman Italy than that offered by Brunt, op. cit. (n. 5, I97I) and Beloch, op. cit. (n. 6), for the question of the profitability of commercial agriculture in the middle and late Republic requires a much more extensive discussion than can be undertaken here and will be taken up in a separate publication.

${ }_{53}$ K. Hopkins, Death and Renewal (I983), IIO-II. Dion. Hal. 6.I3.4, cf. Nicolet, op. cit. (n. 3I), I2I-2.

54 Wiseman, op. cit. (n. 3I); Brunt, op. cit. (n. 5, I988), I45-6. 
of thirteen farms worth six million sesterces, but no evidence allows us to gauge their numbers. ${ }^{55}$ Brunt suggests that the curial class in the late Republic may have numbered over 50,000; Jongman suggests 20,000 for the early Empire. ${ }^{56}$ Unquestionably, citizens worth the HS Ioo, ,oo that qualified a man for membership in this class would have been among those with the economic resources to produce crops for Italy's urban markets. ${ }^{57}$ How many more potential producers might have competed to sell their wares is impossible to determine; in all likelihood, their numbers will have been considerable. The HS roo,ooo that constituted the threshold for inclusion among the decurions was also the lower limit for the first census class, suggesting that the latter is likely to have been rather larger than the former. ${ }^{58}$ Wealthy freedmen, too, would certainly have possessed the resources to invest in commercial agriculture. And if in the late third century members of the second and third census classes commonly owned slaves, first-century members of the same classes are likely to have owned them as well, since there is little reason to think that citizens in the upper census classes had become significantly poorer over the intervening century and a half, particularly if, as is sometimes suggested, the census qualifications for all classes but the fifth had been raised significantly when the sestertius was adopted as the official unit of reckoning in the mid-second century B.C. ${ }^{59}$ Moreover, the number of citizens enrolled in all census categories had increased dramatically with the extension of citizenship to Rome's former socii following the Social War, so that the universe of potential sellers would have greatly expanded as well.

Once again, the archaeological evidence for wine and oil production in this period allows us to put some flesh on the bones of these assertions. The appearance of the "classical villa' and with it the 'slave mode of production' in the early first century B.c. certainly did not doom smaller producers to extinction. All of the modest farms discussed above, with the exception of the Giardino Vecchio site, continued to be occupied throughout the late Republic and into the early Empire. ${ }^{60}$ Far more revealing, however, are the remains of several small farmsteads unearthed near Pompeii. While some of these may have been established in the Augustan period or later, they are important to the argument because they unquestionably co-existed with much larger neighbouring villas of the 'classic' type. Farms like the Stazione, Giuliana, and Villa Regina sites, all near Boscoreale, were clearly modest affairs. ${ }^{61}$ The main farmhouses are only around $500 \mathrm{~m}^{2}$ in size, yet all show unmistakable evidence for the commercial production of wine, indicating that they were competing successfully for a share of the nearby urban market. Moreover, even smaller operations seem to have existed within the walls of Pompeii itself, as Jashemski's excavations of vineyards at the so-called Foro Boario near the amphitheatre and elsewhere demonstrate. ${ }^{62}$ Once again, we cannot know who the owners of these smaller farms and urban vineyards were. ${ }^{63}$ The possibility therefore cannot be ruled out that these properties were included within the agricultural portfolios of members of the senatorial élite. By the same token,

\footnotetext{
55 Cic., Rosc. Am. 20-I.

56 Brunt, op. cit. (n. 5, 1988), 245; Jongman, op. cit. (n. 22), I93.

57 Rathbone, op. cit. (n. 27), I27-37, dating the establishment of the qualification to $c$. I 4 O B.C.; Mattingly, op. cit. (n. 27), I05-6, suggests 89 B.C.; Wiseman, op. cit. (n. 3I), 65 n. 7 proposes 88 в.C.

58 Rathbone, op. cit. (n. 27), I26-32.

59 Crawford, op. cit. (n. 27), I49-5I; Rathbone, op. cit. (n. 27), I32-3; contra, however, Lo Cascio, op. cit. (n. 27), $295-6$.

${ }^{60}$ Above pp. 7-8.

${ }^{61}$ Stazione: M. Della Corte, 'Villa rustica, explorata dal sig. Ferruccio De Prisco ...', NSc I92I, 436-42; Giuliana: A. Sogliano, 'Villa romana in contrada detta Giuliana', NSc I897, 398-402; Villa Regina: S. De Caro, La Villa Rustica in località Villa Regina a Boscoreale (I994); W. Jashemski, 'Recently excavated gardens and cultivated land of the villas at Boscoreale and Oplontis', in MacDougall, op. cit. (n. 37), 64-7I. For a survey of the various agricultural villas around Pompeii, Jongman, op. cit. (n. 22), I I2-20.

62 W. Jashemski, The Gardens of Pompeii, Herculaneum and the Villas Destroyed by Vesuvius (I979), $20 \mathrm{I}-32$.

63 Jongman, op. cit. (n. 22), I28-3I, offering a sceptical rebuttal to the overly confident identifications of J. Day, 'Agriculture in the life of Pompeii', YClS 3 (I932), I77-9 and 204-8.
} 
TABLE 2

WINE

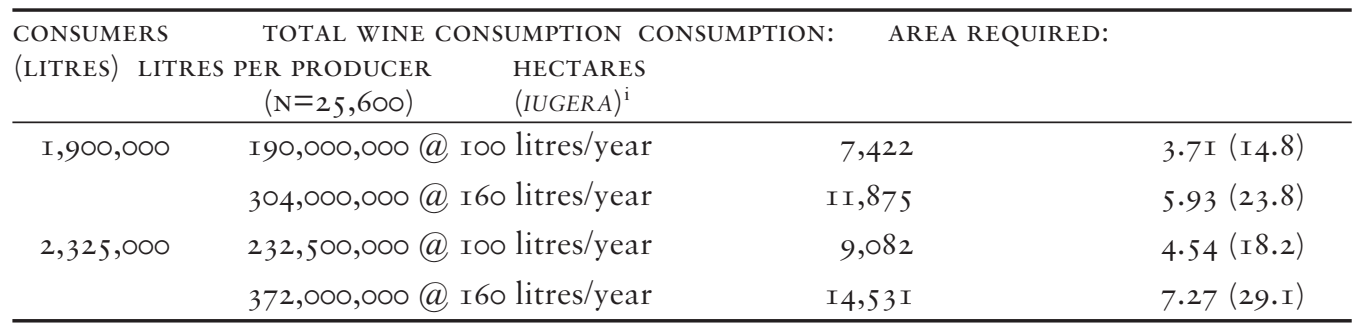

OIL

\begin{tabular}{cccc}
\hline CONSUMERS & $\begin{array}{c}\text { TOTAL OLIVE OIL } \\
\text { CONSUMPTION (LITRES) }\end{array}$ & $\begin{array}{c}\text { CONSUMPTION: } \\
\text { LITRES PER PRODUCER } \\
(\mathrm{N}=25,600)\end{array}$ & $\begin{array}{c}\text { AREA REQUIRED: } \\
\text { HECTARES } \\
(\text { IUGERA) }\end{array}$ \\
\hline I,900,000 & $38,000,000 @$ @ 20 litres/year & $\mathrm{I}, 484$ & 3.37 (I3.5) \\
& $57,000,000 @$ 30 litres/year & 2,227 & $5.06(20.2)$ \\
$2,325,000$ & $46,500,000 @$ 20 litres/year & $\mathrm{I}, 8 \mathrm{I} 6$ & $4 . \mathrm{I} 3(\mathrm{I} 6.5)$ \\
& $69,750,000 @$ 30 litres/year & 2,725 & $6 . \mathrm{I} 6(24.8)$ \\
\hline
\end{tabular}

WHEAT

\begin{tabular}{cccc}
\hline CONSUMERS & $\begin{array}{c}\text { WHEAT CONSUMPTION } \\
\text { (KILOS) }\end{array}$ & $\begin{array}{c}\text { CONSUMPTION: } \\
\text { KILOS PER PRODUCER } \\
\text { (N=25,600) }\end{array}$ & $\begin{array}{c}\text { AREA REQUIRED: } \\
\text { HECTARES } \\
\text { (IUGERA) }\end{array}$ \\
\hline \multirow{2}{*}{ I,900,000 } & $380,000,000 @$ @ 200 kg. per year & $\mathrm{I} 4,844$ & 37 (I48.4) \\
& $505,400,000 @$ 266 kg. per year & $\mathrm{I} 9,742$ & 49.3 (I97.4) \\
$2,325,000$ & $465,000,000 @$ 200 kg. per year & $\mathrm{I} 8, \mathrm{I} 64$ & 45.4 (I8I.6) \\
& $6 \mathrm{I} 8,450,000 @$ 266 kg. per year & $24, \mathrm{I} 58$ & 60.4 (24I.6) \\
\hline
\end{tabular}

${ }^{\mathrm{i}}$ For the assumptions on which calculations of the areas required in Table 2 are based, see Table I.

however, their modest size means that they also could have been owned by men of less exalted status, members of the decurial class at Pompeii or even citizens who ranked below this level. There is in other words no reason to believe that large operations like Settefinestre or Villa I 3 at Boscoreale monopolized the commercial production of wine in the late Republic. Smaller farms continued to hold their own in the marketplace. ${ }^{64}$

To be conservative, then, let us take the figure of 25,600 , comprising senators, equites equo publico, and members of the decurial class according to Jongman's lower estimate, as representing all Italian produces of agricultural surpluses of wine, oil, and wheat destined for the peninsula's urban markets. Table 2 lays out the average market shares for these hypothetical 25,600 producers if each met an equal portion of the demand of I,900,000-2,325,000 urban residents for wine, oil, and wheat. Once again, the arresting features of the table are how small the average market shares are on the assumption that demand was equally divided among all producers and how unimpressive the amounts of land are that each producer would have had to cultivate to meet his share even with urban food requirements at their highest levels. Even supposing that on average 2,325,000 citydwellers each consumed I60 litres of wine a year, the amount of land that each of 25,600

${ }^{64} \mathrm{cf.}$ A. Tchernia, Le Vin de l'Italie romaine (I986), I20. 
producers would have had to work to satisfy his portion of this demand was only about 29 ingera, while olive oil consumed at a rate of 30 litres per person per year would have required the yield of around 25 ingera of orchard on average from every producer. Again, only the demand for wheat provides the economic conditions necessary to support fairly large estates for each of our hypothetical 25,600 producers, but as noted above for Table I, Table 2 takes no account of overseas producers of wheat, and unquestionably a substantial portion of at least Rome's demand for grain in the late Republic was being met by farmers in Sicily, Sardinia, North Africa, and elsewhere, a large but unquantifiable portion of which represented taxation-in-kind. ${ }^{65}$

As with Table I, it is possible to offer some speculative estimates of the average gross profits that commercial agriculture at these levels of demand might have yielded for a group of 25,600 producers. There are no data for olive oil prices in this period, and wheat and wine prices are problematic since what data exist are mainly drawn from the Imperial period. Still, what these prices suggest about agricultural incomes in the late Republic is not encouraging. Duncan-Jones assumes that on average the price of wheat during the Empire would have been between HS 2 and HS 4 per modius, plausible enough on the basis of the prices Cicero gives for wheat in Sicily during Verres' governorship. Frank and Hopkins similarly take HS 3 as a conventional price during the Republic. ${ }^{66}$ At these prices, $465,000,000 \mathrm{~kg}$ of wheat $(=69,924,8 \mathrm{I} 2$ modii) would have brought HS I39,849,624 at HS 2 per modius and HS 279,699,248 at HS 4. At 618,450,000 kg (93,000,000 modii) of wheat, the sums are HS I86,000,000 and HS 372,000,000. ${ }^{67}$ Divided among 25,600 producers, the average gross profit per producer falls between HS 5,463 and HS I4,53 I each. Of course, grain prices could vary significantly from year to year and especially within each year according to the growing cycle. Prices were lowest just after the harvest and rose steadily thereafter until they reached their peak shortly before the next harvest, when stocks were at their ebb. Wealthy growers, who could afford to hold their wheat until prices rose, might therefore reap higher than average prices for it. ${ }^{68}$ Yet even if we double the averages, profits still seem slim. These sums may also represent only the retail prices consumers paid for the wheat. If that is the case, then the wholesale prices that growers received from middlemen for their crops will have been substantially less, significantly lowering their gross profit. ${ }^{6}$ Duncan-Jones has estimated that a minimum wholesale price for wine during the Empire might have been HS 8.5 per amphora, a little more than half of the HS I5 minimum given by Columella. ${ }^{70}$ At HS 8.5 per amphora, the wholesale value of $372,000,000$ litres of wine (= I4,362,934 amphoras) is HS I22,084,942; at HS I 5 the value is HS 2I5,444,OIO. Apportioned among 25,600 producers, the average gross profit per producer ranges between HS 4,769 and HS 8,4I6. Again, however, it is important to bear

\footnotetext{
${ }^{65}$ On the sorts of competitive advantages that state-sponsored grain subsidies during the late Republic could create for overseas producers, see C. Whittaker, 'Trade and the aristocracy in the Roman Empire', Opus 4 (I985), 53-4. On Asia Minor as a supplier of grain for Rome, see C. Nicolet, 'Dîmes de Sicile, d'Asie et d'ailleurs', in Le Ravitaillement de blé de Rome et des centres urbains des débuts de la République jusqu'au Haut Empire (I994), 2I 5-27. On taxation-in-kind see Rickman, op. cit. (n. I6), 36-45; P. Erdkamp, The Grain Market in the Roman Empire. A Social, Political, and Economic Study (2005), 209-20.

66 Duncan-Jones, op. cit. (n. 2), 42, I45-6, cf. Cic., Verr. 2.3.I63, I88-9; Frank, op. cit. (n. 8), I93, cf. 402-3; Hopkins, op. cit. (n. 2), 38 n. 50, 56 n. 79. Cf. Cavaignac, op. cit. (n. 8), 98: Io denarii per Ioo litres of wheat which, at 8.62 litres to a modius, works out at HS 3.5 per modius.

67 One modius of wheat weighs on average $6.65 \mathrm{~kg}$ : Rosenstein, op. cit. (n. 6), 226 n. I9.

68 Note Varro, Rust. I.69.I: profits could double when grain was sold at the right time; Cic., Verr. 2.3.2I4-I5; Erdkamp, op. cit. (n. 65), I49-53.

${ }_{69}$ On the mechanisms aristocrats used to bring their crops to market, see Morley, op. cit. (n. I3); idem, op. cit. (n. 9), I60-6, and for the Empire, J. Paterson, 'Trade and traders in the Roman world: scale, structure, and organization', in H. Parkins and C. Smith (eds), Trade, Traders and the Ancient City (1998), I58-63.

${ }^{70}$ Duncan-Jones, op. cit. (n. 2), 46-8; Columella, Rust. 3.3.Io. One amphora contains 25.9 litres: Duncan-Jones, op. cit. (n. 2), 372. Frank reckons the average price of an amphora of wine at HS 20 for the second and first centuries B.C.: op. cit. (n. 8), I93, 404. However, this appears to be based on the retail price of wine to consumers rather than what a grower could expect to receive.
} 
TABLE 3

MARKET SHARES OF WINE@2,325,000 CONSUMERS

\begin{tabular}{|c|c|c|c|c|}
\hline PRODUCERS & $\begin{array}{c}\% \text { OF } \\
\text { MARKET }\end{array}$ & $\begin{array}{c}\text { AVERAGE SHARE/ } \\
\text { PRODUCER(LITRES) }\end{array}$ & $\begin{array}{c}\text { AVERAGE } \\
\text { INCOME/ } \\
\text { PRODUCER }(\mathrm{HS})^{\mathrm{i}}\end{array}$ & $\begin{array}{l}\text { AVERAGE AREA REQUIRED/ } \\
\text { PRODUCER (HA [IUG]) })^{\mathrm{ii}}\end{array}$ \\
\hline 600 Senators & I3 & 80,869 & $26,540-44,830$ & $40.4(162)$ \\
\hline 5,০oo Equites & $43 \cdot 5$ & $32,347 \cdot 6$ & I0,6I6-I $8,733 \cdot 5$ & I6.2(65) \\
\hline 20,000 Decurions & $43 \cdot 5$ & 8086.9 & $2,654-4,683$ & $4(\mathrm{I} 6)$ \\
\hline
\end{tabular}

\section{MARKET SHARES OF WHEAT @ 2,325,000 CONSUMERS}

\begin{tabular}{lcccc}
\hline PRODUCERS & $\begin{array}{c}\text { \% OF } \\
\text { MARKET }\end{array}$ & $\begin{array}{c}\text { AVERAGE SHARE/ } \\
\text { PRODUCER(KILOS) }\end{array}$ & $\begin{array}{c}\text { AVERAGE } \\
\text { INCOME/ } \\
\text { PRODUCER(HS) })^{\text {iii }}\end{array}$ & $\begin{array}{c}\text { AVERAGE AREA REQUIRED/ } \\
\text { PRODUCER (HA [IUG] })^{\text {iv }}\end{array}$ \\
\hline 600 Senators & I3 & I34,450 & $40,436-80,872$ & $336(\mathrm{I}, 344 \cdot 5)$ \\
5,000 Equites & 43.5 & 53,700 & $\mathrm{I} 6, \mathrm{I} 74-32,349$ & $\mathrm{I} 34(538)$ \\
20,000 Decurions & 43.5 & $\mathrm{I3}, 445$ & $4,043.6-8087$ & $34(\mathrm{I} 34.5)$ \\
\hline
\end{tabular}

\footnotetext{
Assuming a wholesale price range of between HS 8.5 and I 5 per amphora.

ii On the assumptions about yield per hectare on which these calculations are based see Table I.

iii Prices given are retail values, not gross profits to the producer; on aristocratic preferences in the disposal of their crops, see above n. 69. The calculations here assume a retail price of between HS 2 and 4 per modius of $6.65 \mathrm{~kg}$.

iv On the assumptions about yield per hectare on which these calculations are based see Table I.
}

in mind that these figures represent only income before expenses. Net profits, once the latter had been deducted, will have been considerably smaller.

In reality, of course, the market was not divided evenly among all producers; some will have had a far larger share than others. One might suppose, therefore, that senators, with their greater wealth, social prestige, and political clout, would have dominated the markets, selling the lion's share of commodities like wheat, wine, and oil, while those lower in the socio-economic hierarchy had to content themselves with less. Such an assumption might then lead to the conclusion that senators' larger shares of the markets for commodities enabled them to derive a substantially larger income from growing these crops than Table 2 would suggest. Table 3 attempts to test this hypothesis. It is constructed on the assumption that senators' shares of the markets for wheat and wine were two and a half times larger than those of equites equo publico and ten times larger that those of members of the decurial class. ${ }^{71}$ Thus if we take the largest possible hypothetical annual consumption of wine, 372,000,000 litres per year (supposing an urban population of $2,325,000$ and an average annual consumption of I60 litres per person), senators would sell a total of 80,869 litres each, equites 32,348 litres, and decurions 8,087 litres. ${ }^{72}$ Likewise, if we assume the same population and the highest annual consumption of wheat $(266 \mathrm{~kg}$ per person), shares of the market according to the same ratios would be $134,450 \mathrm{~kg}$ per

\footnotetext{
71 These ratios are based on the approximate ratios of senatorial, equestrian, and decurial censuses.

$72(600$ senators $\times 10=) 6,000$ shares $+(5,000$ equites $\times 4=) 20,000$ shares $+(20,000$ decurions $\times I=) 20,000$ shares $=46,000$ shares. $372,000,000$ litres / 46,000 shares $=8,086.9$ litres / share. On that basis, senators would sell a total of $(8,086.9$ litres x 6,000 shares $=)$ 48,52I,400 litres, or $(48,52 \mathrm{I}, 400 / 600=) 80,869$ litres each. Similarly, equites would sell a total of $(8,086.9$ litres $\times 20,000$ shares $=)$ I6I,738,000 litres or (I6I,738,000 litres / 5,000 =) 32,347.9 litres each, while decurions would sell the same total number of litres, but only (I6I,738,000 litres / 20,000=) 8,086.9 litres each.
} 
senator, 53,780 kg per eques, and $13,445 \mathrm{~kg}$ for each decurion. ${ }^{73}$ On the basis of these figures, Table 3 offers estimates of the monetary values of the average shares of senators, equites, and decurions and the amounts of land that might have been required to produce them.

Even granting that senators on average controlled these much larger shares of the market, however, the profits they would have realized seem surprisingly modest: only about HS $26,000-45,000$ per year for wine from vineyards of around I60 ingera in size. What an average share of the market for grain would have brought to a senator is a little more difficult to estimate, since the prices we have for a modius of wheat are apparently retail prices a consumer would pay rather than what a producer might receive. If Morley is correct that producers preferred either to sell their crops 'at the farm gate' or at least to transport them to middlemen in the cities rather than market their crops themselves, thereby sacrificing potential profits in exchange for the security of having the crop disposed of quickly, a producer might have received only half of the retail price of his grain, if that. ${ }^{74}$ The sums reflected in Table 3, therefore, while by no means trivial, scarcely seem large enough to have paid for the lavishness and grandeur that one would associate with a senatorial standard of living, while at the decurial level, the sums seem completely at odds with the lifestyle of local aristocrats in the late Republic that we see reflected, for example, in some of the houses in Pompeii and elsewhere. And of course, Table 3 is built upon the most optimistic assumptions about the numbers of producers, consumers, and average annual consumption, as well as about the absence of competition from wheat-producers abroad. So, realistically, the figures in Table 3 would be much more likely to decrease rather than increase if we had the quantitative data necessary to gauge properly the profitability of commercial agriculture in late Republican Italy.

Once again it is important to stress that neither these calculations nor the tables can pretend to represent an accurate picture of how market shares for wine, oil, or wheat, or the profits they generated were in fact distributed among producers during the middle and late Republic. Rather, their point is purely heuristic, to show just how limited the economic pie was and how few growers could hope for a big piece. The average gross profits hypothesized above for wine, oil, and wheat in the third, second and first centuries B.C. are a far cry from Cicero's rich man's HS I00,000 a year from his estates, to say nothing of his very rich man's HS 600,000. Even at the most generous estimate of the number of consumers, not every potential seller could obtain a large enough share of the market to justify a sizeable investment in commercial farming or to support a luxurious life-style. To be sure, some senators may have realized considerable profits from feeding Italy's citydwellers. The ships of 300 amphoras-burden allowed to senators and their sons under the Lex Claudia of c. 218 B.C. were capable of transporting the wine yield of $15^{1 / 2}$ ingera of vineyards or the wheat produced on 59 ingera of grain fields, and one would not own such a vessel unless one expected to make several trips to market each year. By the late Republic, Cicero claims, the law was regularly ignored..$^{75}$ Distribution of market-share was certainly uneven, and undoubtedly some very large-scale agricultural operations existed. But even assuming that Italy's urban population increased from around I80,000 individuals to a million from the late third to the late second centuries B.C. and then to over

\footnotetext{
$732,325,000 \times 266 \mathrm{~kg}=6 \mathrm{I} 8,450,000 \mathrm{~kg} / 46,000$ shares $=\mathrm{I} 3,445 \mathrm{~kg} /$ share. Senators would thus sell a total of $(\mathrm{I} 3,445$ $\mathrm{kg} \mathrm{x} \mathrm{6,000=)} \mathrm{80,670,000} \mathrm{kg} \mathrm{or}(80,670,000 / 600=)$ I $34,450 \mathrm{~kg}$ each; equites (I3,445 kg x 20,000=) $268,900,000 \mathrm{~kg}$ or $(268,900,000 / 5,000=) 53,780 \mathrm{~kg}$ each; decurions would sell the same total amount of wheat, but only $(268,900,000$ / $20,000=)$ I $3,445 \mathrm{~kg}$ each.

74 Above n. 69.

75 Livy 2I.63.3; Cic., 2 Verr. 5.45. 300 amphoras represented 7,770 litres of wine if one amphora held 25.9 litres: Duncan-Jones, op. cit. (n. 2), 372. At a yield of 500 litres of wine per iugerum, 7,770 litres represents the yield of I 5.5 ingera. 300 amphoras represented $5,985 \mathrm{~kg}$ of grain if one amphora held three modii: loc. cit., and one modius of wheat weighed $6.65 \mathrm{~kg}$ : above n. 67. At an average yield of roo $\mathrm{kg}$ of wheat per iugerum net of seed, $5,985 \mathrm{~kg}$ represents the yield of 59.9 ingera.
} 
two million by the end of the Republic, the market they constituted was simply not big enough to allow every senator to draw an annual income of HS 100,000 or more from the sale of staple crops if the supply-side comprised anything like the number of potential producers suggested above. Every owner of a 50- or Ioo-ingera vineyard who sold his entire crop reduced or eliminated altogether the amount of wine that one or more of the other potential wine-growers could sell. It was a zero-sum game. The only way out of the box imposed by the limitations of the market was to expand it, and just such an expansion occurred in the late second century B.c. when a boom in wine exports from Italy to southern Gaul coincided with Roman military penetration of that region. ${ }^{76}$ That boom enabled some families, like the Sestii at Cosa, to grow rich from exports. ${ }^{77}$ But the size of the Gallic market, estimated at six to fifteen million litres per year, amounted to at most only an additional 586 litres (22.6 amphoras) average share for each of 25,600 potential producers, an extra profit of not more than HS 339 at HS I5 per amphora, and was dwarfed by that of Rome itself and the rest of urban Italy. ${ }^{78}$

Much the same held true for the demand that Roman military forces represented. Grain to feed the soldiers came principally from tributum paid by the Republic's provinces as well as contributions from allies, and not through purchase from Italy's farmers. Wine and oil as well as other foods may have been a different story, however, since some evidence suggests that these items were at least on occasion shipped from Italy. ${ }^{79}$ The size of the market the soldiers constituted fluctuated from year to year according to Rome's military needs, but generally speaking around I00,000 men were serving on average each year between 200 and 49 B.C. ${ }^{80}$ On the assumption that they consumed wine and oil at the same average rates as civilians and that Italian growers supplied all of it, their numbers would have increased the size of the civilian market by no more than Io per cent if the latter was around one million and by 4 or 5 per cent if Italy's urban population numbered $2,325,000-\mathrm{I}, 900,000 .^{81}$

Moreover, the tables undoubtedly understate the extent of the challenges producers faced. During the third and second centuries B.C. the urban market was in reality certainly far smaller than Table I assumes, since the great increase in Italy's urban population was largely a first-century phenomenon, while the estimate of 23,300 potential sellers may well be too low if members of the first census class typically owned at least three adult male slaves. ${ }^{82}$ Consequently, competition during this period is likely to have been even more

\footnotetext{
76 See S. Dyson, The Creation of the Roman Frontier (I985), I46-60 on the military and diplomatic events.

77 D'Arms, op. cit. (n. 2), 55-62; E. Will, 'The Roman amphoras', in A. McCann et al. (eds), The Roman Port and Fishery of Cosa: A Center of Ancient Trade (I987), I72-6.

${ }_{78}$ Estimates of the size of the Gallic market: Tchernia, op. cit. (n. 64), 85-7; Morley, op. cit. (n. 9), II3.

${ }^{79}$ Grain: Erdkamp, op. cit. (n. 26), 84-I2I; wine: ibid., 34 and n. 30. Shipment from Italy: Livy 37.27.I-3; Plut., C. Gracch. 2.5.

${ }^{80}$ cf. Hopkins, op. cit. (n. 2), 35. Brunt op. cit. (n. 5, I97I), 422-72, offers no average for this entire period. For the years 200-I67 B.C. he indicates that the annual average could be as high as I3I,000 for both land and naval forces, but suggests that some of Afzelius' figures for allied contingents, on which Brunt bases his estimates, may be too high. If so, he indicates that the average may be only I07,000: op. cit., 425. For the period I66-9I B.C. Brunt offers no figure for the average number of soldiers, op. cit., 426-43, but the average number of legions annually in the field derived from his estimates for these years is 7.5 . On the assumption that each legion comprised 5,500 citizen and 6,700 allies: Rosenstein, op. cit. (n. 6), 258 n. 6I, cf. Brunt, op. cit., 677-86, the average number of soldiers is 9I,500. Brunt reckons the average number of men in the legions between 70 and 49 B.C. to be 90,000: op. cit., 447 . Between the outbreak of the Social War and Sulla's victory in 82 B.C. as many as 300,000 men were mobilized on occasion: Brunt, op. cit., $435-45$, but these forces were not kept under arms for more than a few years, and their numbers would not affect the overall average by very much. Yet even if the average were increased to IIO,000 or I20,000, it would not affect the point being made here.

${ }^{81}$ Adult men obviously ought to have consumed more wine and oil on average than women and children, whose consumption is included in the average figures for the civilian market. However, we do not know how much wine soldiers were issued with as a part of their rations or under what circumstances. Amounts may have been strictly limited to preserve discipline, while hard campaigning or rapid movement is likely to have made a steady supply of wine and oil difficult to maintain.

82 Urban growth: above n. 2 I.
} 
intense than Table I suggests. And when that first-century urbanization finally did occur, greatly expanding the market for commercial growers, competition among them certainly increased in step with it - if it did not in fact grow even stiffer. Over the course of the second and first centuries B.c. enormous sums of money flowed into the hands of nonsenatorial Romans and Italians who in one way or another had found a way to profit from the growth of the Republic's imperium abroad, and the result in all likelihood was a growth in the size of the wealthy classes far in excess of the very small increase in producers that Tables 2 and 3 postulate over Table I. Moreover, by the late Republic the local markets of Campania may have become integrated into the metropolitan supply system through the middlemen who regularly made the rounds of them, so that in this way small farmers there who disposed of some of their crops at the nundinae would have further enlarged the pool of producers vying for market share at Rome. ${ }^{83}$ Consequently, Tables 2 and 3 also significantly under-estimate the degree of competitive pressure to which the limited urban market, even at its greatest extent, would have subjected producers. Finally, it is important to bear in mind that urban demand would also have depended to a significant extent on how much money the urban economy was putting into the hands of its residents. Temple construction and other large-scale building projects were intermittent, and so levels of employment could vary significantly from year to year, affecting the amount of food city workers could afford to buy and consequently the degree of competition producers faced in meeting that demand.

\section{ARISTOCRATIC ATTITUDES}

Certainly, much of what we know about aristocratic attitudes towards farming and investment bears out the impression that the tables and calculations convey. No one who reads Cato's De agricultura, for instance, can fail to be struck by his extreme concern for saving money. A farm owner, he advised, should be 'a seller, not a buyer', and slaves should be kept constantly at work because 'if nothing is being done, there will be expense none the less'. ${ }^{84}$ No economy seems beneath his notice, even to the point of selling off old or sickly slaves to spare the expense of feeding them. ${ }^{85}$ For Varro, too, advising his readers amid the much greater affluence of the mid-first century B.C., thrift ought to be a constant concern for any grower trying to squeeze a profit out of his farm. ${ }^{86}$ This attitude was probably congenial to Cato's temperament at least, and it certainly reflected an aristocratic ideal of frugality, but that ideal itself was obviously rooted in the practical imperatives of commercial agriculture during the Republic. ${ }^{87}$ Where competition is vigorous and demand limited, profit margins are likely to be thin for most sellers, and rigorous cost control would often have been the difference between making money and losing it. ${ }^{88}$ Therefore both Cato and Varro insist that neither the vilicus nor anyone else leave the farm except on a necessary errand and with permission. Cato goes even further, laying down a lengthy list of dos and don'ts for his vilicus, while Varro emphasizes that a vilicus must keep a close eye on equipment not kept under lock and key to guard against theft. ${ }^{89}$ 'These injunctions are inspired by a number of motives, above all the need for constant surveillance of

\footnotetext{
${ }^{83}$ For sources, discussion, and further literature on the role of local Campanian markets in supplying Rome in the first century A.D.: Morley, op. cit. (n. 9), I66-74; it is not implausible to assume that this network was in place by the last decades of the Republic.

84 Cato, Agr. 2.7, 39.2.

85 e.g. Agr. 2.4, 37.2-3, I38. Slaves: Agr. 2.7; Plut., Cato Mai. 4.4, although A. E. Astin, Cato the Censor (I978), $264-5,350$, believes that in the latter case Cato did not in fact practise what he preached.

86 e.g. Rust. I.8.I, I.8.5-6, I.II.I, I.I3.6, I.22.I-2, I.22.6, I.22.53.

87 cf. Plut., Cato Mai. 4.I-5.I; Seneca, Ep. 94.27.

88 cf. Astin, op. cit. (n. 85), 260-I, and for the Empire, Paterson, op. cit. (n. 69), I 58.

${ }^{89}$ Agr. 5.I-5; Rust. I.I6.5, I.22.6.
} 
the work force if the villa is to be profitable. ${ }^{90}$ The general stress on self-sufficiency throughout the De agricultura and the De re rustica - growing the food the slaves required and producing on site as much as possible of everything else needed to operate the farm - also makes perfect sense where making money depends on limiting expenditures. ${ }^{91}$ While Cato and Varro may have lacked the double-entry book-keeping and other accounting tools that would have enabled them to chart precisely the relationship between income and expenses, one does not need an advanced degree in business administration to understand that where returns are small and hard-won, excessive costs can easily turn gains to losses. ${ }^{92}$ For sizeable profits seem to have been rare: Cato thought that a farmer who held his crops back until market conditions enabled him to sell at a good price not only made money but enhanced his virtus and won gloria thereby. ${ }^{93}$ Varro, too, emphasized the need for enough storage capacity to enable a wine-grower to delay the sale of his crop until the market was ripe. ${ }^{94}$ Surprisingly, though, both Cato and Varro are quite reticent about just how much money a grower could make producing wine, oil, wheat or any of the other staple crops that city-dwellers depended on. Their silence undoubtedly stems in part from an aristocratic disdain for too close an involvement with the marketplace. ${ }^{95}$ Varro, in fact, says very little about the critical task of selling one's crops, although Cato, reflecting his less exalted roots, is quite explicit about the terms a grower should set in his contracts with buyers. ${ }^{96}$ Yet Varro displays no such fastidiousness when it comes to the strikingly large gains to be realized from the sale of the products of villicata pastio, the raising of such exotic items as dormice, thrushes, peacocks, or wild boars for the luxury market. Varro's frankness about these sums, over which some of his interlocutors become positively giddy, might suggest that the ordinary profits from more prosaic crops were generally not large enough to generate much excitement. ${ }^{97}$ Rather, properties near urban centres producing speciality crops for niches in the marketplace were where aristocrats who wanted to make money from agriculture put their energies. ${ }^{98}$ Even here, however, they would not necessarily escape the pressure of competition from smaller producers. ${ }^{99}$

Still, even the most vigilant management of an estate cannot overcome basic market forces, and at some point in his life, if Plutarch is to be believed, Cato gave up on agriculture as a profit-making venture and devoted his commercial energies elsewhere. ${ }^{100}$ Nor does he seem to have been alone in this. The senators' all but unanimous opposition to the

\footnotetext{
90 Morley, op. cit. (n. I3), 2 I8.

91 Astin, op. cit. (n. 85), 244-5.

92 On the relative lack of importance of sophisticated accounting techniques like double-entry book-keeping to ancient commercial farming: D. Rathbone, Economic Rationalism and Rural Society in Third-Century A.D. Egypt: The Heroninos Archive and the Appianus Estate (I99I), 385-6; Morley, op. cit. (n. 9), 73-4.

93 Agr. 3.2.

94 Rust. I.22.4.

95 Morley, op. cit. (n. I3), 2I4-20, cf. idem, op. cit. (n. 9), I60-6.

96 Agr. I36-50. As Morley points out, op. cit. (n. I3), 215, Varro has to resort to 'staging a murder to break off his characters' discussion of the marketing of produce' at the end of Book I.

${ }_{97}$ Rust. 3.2.13-I8. That the sums Varro reports here bear any relation to the profits such pursuits actually realized must remain open to doubt in view of W. Scheidel's demonstration, 'Finances, figures and fiction', CQ 46 (I996), 222-37, that virtually all figures for sums of money reported in the imperial period 'are merely conventional figures which cannot automatically be accepted as rough approximations or rounded variants of actual figures known to the authors', quotation from p. 223.

98 cf. N. Purcell, 'The Roman villa and the landscape of production', in T. Cornell and K. Lomas (eds), Urban Society in Roman Italy (I995), I 57-9.

99 Evans, op. cit. (n. 6), I44; Purcell, op. cit. (n. 98), I 55.

100 Cato's motivation, according to Plutarch, Cato Mai.2I.5, was to focus on investments that were safe and secure and could not be threatened by the weather. Cato's desire for investments immune to damage from storms and other natural phenomena is understandable in and of itself, but it is also not inconsistent with narrow agricultural profitmargins that left little room for misfortune. When making money was difficult even under the best of circumstances, the impact of accidents of nature could quickly turn potential profits into actual losses. Astin, op. cit. (n. 85), 250, doubts the veracity of Plutarch's claim but on insufficient grounds.
} 
Lex Claudia suggests that the patres were quite unhappy to be precluded from the profits of overseas trade and thereby limited to the gains they could make from farming. ${ }^{101} \mathrm{In}$ light of this incident, the ratios of slaves the Senate required from the various categories of citizens in 2 I 4 B.C. are highly suggestive. While citizens in the first class possessed at a minimum three times the wealth of those in the third class and were liable to contribute three times as many slaves, millionaires with wealth at least ten times as great as those in the first census class were only expected to offer slightly more than twice as many slaves. The latter ratio might well be taken to indicate that while some at the top of the economic ladder may have owned many times more slaves than citizens in the first class around the turn of the third century, typically they did not. And if wealth is not a good predictor of the extent of slave-ownership, then at least at this point, aristocrats would seem not to have been investing their money in slave-based commercial agriculture. Other avenues to gain appear to have been much more attractive. Cato, when asked what were the best ways of increasing one's family fortune, famously responded: 'Good pasturing'; 'Fairly good pasturing'; 'Poor pasturing'; and 'Cultivating crops'. Asked 'What about usury?' he shot back, 'What about killing a man?' ${ }^{02}$ What the anecdote very clearly illustrates, besides Cato's wellknown opposition to money-lending, is that Cato's questioner, while not very eager to invest in pasturage, was quite interested to know whether he could make money by lending at interest. ${ }^{103}$ Significant, too, is Cato's failure to mention viticulture in this context. His silence seems of a piece with the attitudes of other members of his class, for not until the Julio-Claudian period does evidence for the political élite's interest in viticulture become abundant, not surprising if there was little money in wine in the middle and late Republic. ${ }^{104}$ Rather, around the middle of the second century B.c. 'everyone', according to Polybius, was involved in one way or another with the business of public contracts, suggesting that here, not in commercial agriculture, was where there was money to be made. ${ }^{105}$

Much the same may have been true in the late Republic. Senators' involvement in various non-agricultural commercial pursuits is well-documented, and there is no need to recapitulate the evidence here. ${ }^{106}$ But it is generally taken for granted that such activities represented merely the icing on the financial cake, while their farms formed the cake itself. So Hopkins, for example, points to the considerably larger average incomes enjoyed by the leading landowners in England in I80 c compared with those of the richest merchants to suggest that 'the ratio of agrarian to non-agrarian incomes in Rome, even in the exceptional conditions of the Republic, was almost certainly higher'. ${ }^{107}$ But was it? We know, for example, that Cicero inherited a group of shops in Puteoli that paid him around HS I00,000 annually, while two insulae on the Aventine and the Argiletum brought in about the same amount. Nor did these properties contribute anything like the majority of Cicero's income: the revenue from these insulae merely furnished his son's allowance while he was away studying in Athens. ${ }^{108}$ Yet each of these sums is equal to the total annual income that Cicero elsewhere claims (perhaps only hypothetically) that he drew from his

\footnotetext{
101 Above n. 75.

102 Cic., Off. 2.89 , cf. Columella, Rust. 6 praef. 4-5; Plin., HN. I8.29-30.

103 cf. Cato, Agr. I.I.

104 Purcell, op. cit. (n. 22), 5-9. Purcell, op. cit. (n. 98), I 56-7, has subsequently backed away from this conclusion but without sufficient justification in my opinion.

105 Polyb. 6.17.2-4, cf. E. Badian, Publicans and Sinners; Private Enterprise in the Service of the Roman Republic (I972), 46 on the considerable extent of participation in the public companies and op. cit., $2 \mathrm{I}-36$ on the sizeable sums involved in the contracts, mainly for military equipment, building, and mining, against Frank, op. cit. (n. 9), I $48-57$, who focuses on the more limited profits to be gained from port dues and grazing and fishing fees. See also Walbank, op. cit. (n. 26), 692-4.

106 e.g., Wiseman, op. cit. (n. 3I), I97-202; D’Arms, op. cit. (n. 2), 48-7I; Frank, op. cit. (n. 9), 394-6.

107 Hopkins, op. cit. (n. 2), 52-3.

108 Puteoli: Cic., Att. 365 (I4.II).2, cf. 363 (I4.9).I; insulae: Att. 27I (I2.32).2, 394 (I5.I7).I, 409 (I6.I).I; B. Frier,

'Cicero's management of his urban properties', CJ 74 (I978/79), I-6.
} 
estates. ${ }^{109}$ Possibly Cicero's finances, being those of a novus homo and highly successful advocate, were not typical of senators in general, but the tables and calculations presented above strongly suggest that this explanation is incorrect and that in fact a senator's urban properties and other non-agricultural commercial ventures provided a much greater share of his ordinary income than revenue from the sale of staple crops. ${ }^{110}$ Perhaps we hear little of such activities owing to the accidents of the sources, but more likely aristocratic attitudes towards commerce enjoined a decorous reticence, while the organization of such enterprises enabled senators to hide their involvement behind freedmen and other agents. ${ }^{111}$ The same strategy may also have masked many aristocrats' investment in maritime trade. ${ }^{112}$ Even these sources of revenue, however, may have paled in comparison to the income derived from money-lending. Like Cato's questioner a century earlier, late Republican aristocrats were eager to make loans, particularly to provincials where, if the well-known 48 per cent annual interest on Brutus' loan to the Salaminians can be taken as anything like typical, the profits could be spectacular. Even the legal I2 per cent annual interest permitted by law represented a handsome return on an investment. Here rather than land is where senators are likely to have invested the lion's share of their plunder from war and provincial rapacity when looking for the long-term income necessary to support the luxury and open-handedness essential to advance a political career. ${ }^{113}$

In many cases, however, the profits of empire may not have been invested at all. Hollander has recently offered a sophisticated and cogent refutation of Hopkins' claim that the dramatic increase in Republican coinage that began in the later decades of the second century was due to an equally sharp increase in the volume of trade in this period, which in turn necessitated an enlargement in the supply of money to facilitate exchange. ${ }^{114}$ Instead, Hollander has shown that the increase in the demand for specie resulted from an increased desire among Italians to hold their wealth in that form rather than any other. Hollander traces this development to the dangerous and uncertain conditions of the late Republic that led people to want to keep their wealth in a liquid form. It is equally possible, however, that the lack of opportunities for profitable investments in agriculture also contributed to this surfeit of cash.

This is not to say that some did not try their hand at grapes or other commercial crops. Just after the end of the Hannibalic War the Republic's creditors were eager to get their loans repaid because the war had brought an abundance of agricultural land onto the market and to purchase it they needed cash. In order to satisfy them, the Senate allowed them the use of public land within fifty miles of Rome at a nominal rent. ${ }^{115}$ Many of the farms in this zone would have been prime candidates for market agriculture. ${ }^{116}$ And given

\footnotetext{
109 Parad. 49, quoted above n. II.

110 On investments in urban property: P. Garnsey, 'Urban property investment in Roman society', in M. I. Finley (ed.), Studies in Roman Property (I976), I23-36; B. Frier, Landlords and Tenants in Imperial Rome (I980), 2I-5 (who, however, believes that urban investments constituted only a small part of an aristocrat's portfolio); H. Parkins, 'The "consumer city" domesticated? The Roman city in élite economic strategies', in eadem (ed.), Roman Urbanism. Beyond the Consumer City (I999), 83-III, especially 92-3; D. Hollander, Money in the Late Roman Republic (2007), II2-I3.

111 D’Arms, op. cit. (n. 2), 20-47; A. Kirschenbaum, Sons, Slaves and Freedmen in Roman Commerce (I987). Cf. the sources of Attacus' wealth and Nepos' portrayal of them: Nep., Att. I4.2-3, with N. Horsfall, Cornelius Nepos. A Selection, Including the Lives of Cato and Attacus (1989), commentary ad loc.

112 Plut., Cato Mai. 21.6; cf. Aldrete and Mattingly, op. cit. (n. 24), I87-8.

113 Shatzman, op. cit. (n. 2), 75-9; E. Badian, Roman Imperialism in the Late Republic (I968), 82-6; Frank, op. cit. (n. 9), 387-9. Compare the 48 per cent interest rate, later reduced to 24 per cent, that the city of Gytheum was forced to pay to the Cluatii: $S I G^{3} 748.15-40$.

${ }^{114}$ K. Hopkins, 'Taxes and trade in the Roman Empire (200 B.C-A.D. 400)', JRS 70 (I980), I06-I2; Hollander, op. cit. (n. IIO), I37-55.

115 Livy 3I.I3.6-9.

116 Morley, op. cit. (n. 9), 83-I07. During his censorship in I85 B.C., Cato criticized an otherwise unknown Furius for tapping the public water supplies to irrigate his farms, perhaps as part of a scheme to increase the commercial potential of the land: ORF4 Cato the Elder, no. IO2, cf. Livy 39.44.4; Plut., Cato Mai. I9.I; Astin, op. cit. (n. 85 ), 84.
} 
Cato's and Varro's detailed instructions in the De agricultura and the De re rustica for the management of estates producing crops for market, we may accept the common view that these works were intended at least in part as a guide for those interested in commercial farming, just as the Senate's authorization of the translation of Mago's agricultural work may have had similar ends in view. ${ }^{117}$ The populations of Rome and Italy's other towns were growing during the second and first centuries B.C., money was flowing at least intermittently into the hands of urban workers, and this increased demand ought to have attracted investment in the production of food to meet it. Unquestionable, too, is the massive influx of wealth from Rome's conquests and other sources into the purses of Italy's upper classes. But a willingness to invest is not the same as a guarantee of making money, and while a few senators may have made quite a lot of it from the sale of wine from new vineyards or other crops, the market's inability to absorb the produce of a large number of new estates would have meant disappointment for many other investors. ${ }^{18}$ Cicero's remarks in his third speech against Verres about the difficulties in making a profit growing grain and the general uncertainty of the enterprise may contain more than a little hyperbole. ${ }^{119}$ Still, he must have expected his statements to accord well enough with his listeners' experiences and expectations to be effective in winning their sympathy for his Sicilian clients' plight. A general disenchantment with the prospects of commercial farming may also to some extent lie behind the rise of tenancy in the first century B.C., for among the other advantages the practice offers to a landowner is that it shifts much of the risk involved in marketing a crop to the tenant, relieving the landowner of the need to compete directly against other producers. ${ }^{120}$ And if, as seems increasingly likely, the population of Italy was rising during the second and into the first centuries B.C., competition for access to land will have been intensifying as well, thereby easing the task of finding tenants. ${ }^{121} \mathrm{On}$ the other hand, many aristocrats may have adopted an attitude towards their estates that "modern economists would describe as "profit-satisficing" and "risk-averse". That is, they set a level of return with which they would be satisfied - often arrived at arbitrarily, or by comparison with the return from neighbours; above that level other goals might apply - the pursuit of pleasure or leisure, or the avoidance of further hassles'. ${ }^{122}$

Other outlets for an aristocrat's surplus crops may also have loomed far larger in his economic calculations than is commonly supposed. Quite possibly much of what a senator grew went simply to feed himself, his family, an elaborate urban household staff, and his guests. The well-known case of Trimalchio, whose estates were supposed to be so vast that he had no need to buy anything despite the lavishness of his life-style and the size of his establishment, may be less an absurdity than a common practice taken to absurd lengths. ${ }^{123}$ Much of what remained beyond his immediate consumption needs is likely to have been stored - both to carry an aristocrat's household through lean times and more importantly as a reserve ready to be distributed to hungry dependents and others on such occasions as a means of establishing and maintaining his social power in the countryside and elsewhere. ${ }^{124}$ Only the assumption that the money a senator required to live as his

\footnotetext{
117 Mago: Pliny, HN I8.22-3, cf. Columella, Rust. I.I.I3; Varro, Rust. I.I.Io.

118 On those senators and equites known or likely to have produced fine wines, see Tchernia, op. cit. (n. 64), II6-I8. 119 Cic., Verr. 2.3.227-8, cf. Erdkamp, op. cit. (n. 65), I64-6.

120 Hopkins, op. cit. (n. 2), I26, cf. I Io for other advantages of tenants. P. de Neeve, Colonus: Private FarmTenancy in Roman Italy during the Republic and the Early Principate (I984), II9-74, argues that the rise of tenancy in the first century в.C. was due in considerable part to higher prices for wheat, which seems implausible in view of the abundant sources of supply available. L. de Ligt, 'Studies in legal and agrarian history II: tenancy under the Republic', Ath. 88 (2000), 377-9I, argues, contra de Neeve, that tenancy was widespread in earlier centuries, but his arguments are not convincing: Rosenstein, op. cit. (n. 6), I8I-2.

121 De Ligt, op. cit. (n. 6), 725-57; Rosenstein, op. cit. (n. 6), I4I-69.

122 Paterson, op. cit. (n. 69), I 58-9, describing aristocratic farmers in the imperial era.

123 Petron., Sat. 38, 48; cf. Cic., Leg. Agr. 2.78; Horace, Epist. 2.2.I60; Virg., G. 4.I27-47, especially I33; and for the Empire, Whittaker, op. cit. (n. 65), 58-6I.

124 Purcell, op. cit. (n. 98), I69-70.
} 
station demanded must have come mainly from market-agriculture compels the conclusion that the proportion of his crops sold would have had to have been far greater than what was consumed by his own establishment or given away in the interest of creating bonds of dependence. ${ }^{125}$

A similar petitio principii underlies estimates of how much land particular aristocrats owned, the extent of their estates being deduced from the size of their fortunes. ${ }^{126}$ Yet if most senators did not derive the bulk of their incomes from commercial agriculture, then we have no warrant to assume that a wealthy senator's landholdings must have been vast. Possibly some were, but it is striking, in view of the willingness of our sources to put specific monetary values on particular properties and individual fortunes, that we are never told straight out how big any Republican landholding was. Indirect evidence is sometimes brought to bear, but its reliability is suspect. So L. Domitius Ahenobarbus' offer in 49 B.C. of 40 ingera (if that is the correct reading in the text) of land from his own property to several thousand soldiers serving under his command at Ariminum is commonly taken to demonstrate the enormity of those estates. ${ }^{127}$ But Domitius' promise was in fact nothing more than a desperate ploy to retain the loyalty of raw levies in a hopeless position and facing the impending onslaught of Caesar's vastly superior veterans. Domitius would have promised anything at that point, whether he could make good on those promises or not. The incident is hardly a reliable indication of the size of his holdings. Perhaps a better gauge of their extent can be found in an incident occurring not long afterwards, when Domitius left Cosa and Igilium, where he apparently had estates, with seven fast ships filled with his 'slaves, freedmen, and coloni'. ${ }^{128}$ Even assuming that these last were tenants on his estates (which is not at all certain), seven boatloads of men, while a substantial group, scarcely suggest a labour force sizeable enough to have worked holdings in the thousands of ingera. Perhaps a shortage of boats limited the number of dependents Domitius could take with him, but it is equally plausible that this fairly small force was all he could muster from his farms. A few years earlier, Catiline made his last stand surrounded by men who were perhaps his coloni. ${ }^{129}$ Yet even if these men were tenants (again, by no means certain), they clearly constituted no more than a handful of troops. ${ }^{130}$ And although some have asserted that Pompey and his father must have owned vast estates in Picenum since each raised an army from his tenants there, the evidence is quite clear that these recruits were clients who do not appear to have farmed either the junior or senior Pompey's lands but their own. ${ }^{131}$ Even Cicero's claim in 63 B.C. that all the territory around Praeneste had fallen into the hands of a few men may be nothing more than hyperbole in an effort to convince the intended beneficiaries of Rullius' agrarian law that their allotments would quickly meet a similar fate. ${ }^{132}$

If prospects for earning the abundant incomes that senators needed to advance their political careers from growing staple crops to feed Italy's urban population were unpromising for more than a few producers, then we must remove the aristocracy's formation of large, commercial estates from the central role they have long played in reconstructions of the social and economic developments in the middle and late Republic. Despite the dramatic increase in the population of Rome and the urbanization of Italy, the possibility

\footnotetext{
125 As Morley, op. cit. (n. 9), I60, cf. idem, op. cit. (n. I3), 216 assumes.

126 So e.g. Shatzman, op. cit. (n. 2), 35.

127 Caes., B. Civ. I.I7; some editors, however, read 'quaterna in singulos iugera'.

128 Caes., B. Civ. I.34.2, cf. 56.3; cf. J. Carlsen, The Rise and Fall of a Roman Noble Family. The Domitii Ahenobarbi I96 B.C.-A.D. 68 (2006), 105-6.

129 Sall., Cat. 59.3. However, P. McGushin, C. Sallustius Crispus, Bellum Catilinae. A Commentary (I977), 284 argues that the reading calonibus, 'soldiers' servants', is to be preferred.

${ }_{130}$ On the uncertain status of Domitius' and Catiline's coloni: de Neeve, op. cit. (n. I20), I75-92.

131 Army from tenants: e.g. E. Badian, Foreign Clientelae (264-70 B.C.) (I958), 229 n. I, cf. 228-9. Clients: e.g. R. Seager, Pompey. A Political Biography (I979), 8; de Neeve, op. cit. (n. I20), I87-9I, who concludes these soldiers were not tenant-farmers.

132 Cic., Leg. Agr. 2.78.
} 
of selling wheat, wine, and oil to sustain that growth will not have led many aristocrats to pour money into land, displacing legions of smallholders and thereby creating the horde of urban consumers of the crops their slaves would produce. Certainly, senators owned farms and derived a portion of their incomes from them, but agriculture was not where they expected to make their money. Apart from direct provincial exploitation, money-lending and urban enterprises offered much more enticing business opportunities. And while some senators undoubtedly may have used a portion of the spoils from their conquests or provincial administration to increase their landholdings, prestige more than profit is likely to have been the end in view, the accumulation of symbolic rather than economic capital. ${ }^{133}$ If as Hopkins asserted 'landholdings were the geographical expression of social stratification', then it is very easy to believe that investments in land were determined more by where one expected or aspired to rank within the social hierarchy than by a hardheaded calculation of the likely monetary returns. ${ }^{134}$ Aristocratic families with more than one or two sons to launch on political careers needed to equip them with the agricultural accoutrements essential to the status that they aspired to maintain. New men required estates extensive enough to validate their claims to membership in the political élite. ${ }^{135}$ The Roman aristocracy celebrated agricultural productivity, and undoubtedly their villas did produce a range of crops. ${ }^{136}$ But while these farms may have helped make possible the growth of Italy's cities by supplying some of the food they required, their extent can be measured neither by the profits of empire nor aristocrats' need to make money.

\section{APPENDIX}

Obviously Livy's account of the episode he describes at 24.II.7-9 cannot simply be taken at face value, since the numbers it implies are inconsistent with the context. The Senate in 2I4 B.C. had authorized the construction and manning of Ioo new warships. ${ }^{137}$ On the reasonable assumption that all of these were quinquiremes with a complement of 340 oarsmen each, this fleet would have required 34,000 rowers. On the further assumption that the senators expected to meet this need entirely from slave conscripts, the number of oarsmen that the arrangements Livy describes at 24.II.7-8 would yield is far in excess of this requirement. Three hundred senators each supplying eight slaves would produce 2,400 oarsmen. If we suppose that the figure 300,000 asses represents the minimum amount of property required to qualify for cavalry service equo privato, 23,000 cavalrymen each supplying five slaves produces I I 5,000 slaves. We might suppose that after four years of warfare and the heavy casualties suffered by Roman forces, the surviving cavalrymen were much reduced from their pre-war numbers. But even halving the figure to II,500 and so bringing the number of slaves conscripted down to 57,500 does not solve the problem of too many rowers for the size of the fleet, particularly if one takes

\footnotetext{
${ }^{133}$ For this reason many of the very high land values that appear in our sources, for example Sex. Roscius' thirteen farms worth six million sestertii: Cic., Rosc. Am. 20-I, cf. Frank, op. cit. (n. 8), 393 and Duncan-Jones, op. cit. (n. 2), 52 n. 4 for other prices, will have been less a function of the profits these estates generated than of an inflationary situation in which too much money was chasing a limited number of desirable properties: E. Rawson, 'The Ciceronian aristocracy and its properties', in Finley, op. cit. (n. IIO), 95; de Neeve, 'The price of agricultural land in Roman Italy and the problem of economic rationalism', Opus 4 (I985), 83-4. On the money supply at Rome in the late Republic see now W. V. Harris, 'A revisionist view of Roman money', JRS 96 (2006), I-24. This oversupply of money was coupled with a mechanism for determining land-values that depended to a considerable extent on a citizen declaring before the censors what his property was worth rather than any objective system of appraisal: Brunt, op. cit. (n. 5, I97I); I5-I6; C. Nicolet, The World of the Citizen in Republican Rome (1980), 67-73.

134 Hopkins, op. cit. (n. 2), 7.

135 Parkins, op. cit. (n. I IO), 90. On aristocrats buying and selling property in the late Republic: Rawson, op. cit. (n. I33).

136 Purcell, op. cit. (n. 98).

137 Livy 24.II.5-6.
} 
into account the slaves levied from citizens in the 50-100,000 and 100,000-300,000 as ranges, who were certainly more numerous than those at the 300,000 as level.

Yet Livy's account of the episode in 2 I4 B.c. cannot simply be rejected. The same method of levying slaves to serve as oarsmen was again invoked, abortively as it turned out, in 2IO B.C., when another fleet needed to be manned, and this second episode is certainly genuine. ${ }^{138}$ When the slave-owners in 2 Iо B.C. protested that they had no more slaves to give, a compromise was reached whereby citizens in the categories obligated to provide slaves were allowed to substitute voluntary loans in money and plate, with the senators themselves setting an example of financial sacrifice and the other citizens following suit. From these funds oarsmen were apparently either hired or purchased (it is not clear which). The veracity of this episode is certain, for Livy subsequently records three instalments authorized by the Senate to repay these contributions, in 204, 200, and I96 B.C. ${ }^{139}$ The second of these resulted in the creation of the trientabulum lands. Because the preparations for the second war with Macedon were under way in 200 B.C., the treasury lacked ready cash to satisfy its creditors. Therefore the Senate offered them the use of portions of the ager publicus within fifty miles of Rome at a nominal rent, which the creditors gladly accepted. These were the trientabulum lands and were a genuine category of public land covered under the provisions of the lex agraria of III B.C. ${ }^{140}$ The link between the trientabulum lands and the attempt to conscript slaves in 2IO B.C. makes it very hard to reject the latter as unhistorical. Yet if the attempt to conscript slaves in 2IO B.C. must be accepted, then its precedent in $2 \mathrm{I} 4$ B.C. ought to be accepted as well. On general grounds, too, the case for accepting the veracity of Livy's report of the conscription of slaves in 2I4 B.C. seems difficult to dismiss. The incident is a minor one, and it is not easy to come up with a plausible reason why it would have been invented. The account is simply one more of Livy's regular reports of the Senate's annual arrangements for waging the struggle against Hannibal, of a piece with the year-by-year reports of numbers of legions and ships, their dispositions, and the commanders assigned to them, which are in the main accepted as accurate by most scholars of the period.

However, accepting the veracity of Livy's reports of arrangements to man the fleets in 2I4 and 2 Iо в.C. entails the further problem of reconciling the implications of each episode, for in 2IO B.C. the Senate's attempt to require citizens to contribute more slaves was stymied by the slave-owners' insistence that they simply had no more slaves to give. Yet if we accept the numbers of slaves implied by the arrangements for 2I4 B.C., there ought to have been plenty of slaves still available four years later to serve in the fleet. Even assuming that many of the slaves who had died in the interval could not be replaced owing to the financial exigencies imposed by the war on their owners or that others had run away, it is difficult to explain how slaves could be in such short supply, even allowing for exaggeration in the complaints of the slaveowners recorded by Livy. ${ }^{141}$

This puzzle can be resolved by assuming that the slave-owners' complaint was not that they in fact had no more slaves to give but that they could not spare the slaves they had left. Another incident from 2 I4 B.C. supplies a parallel. When the censors of that year reviewed the list of assidui, they found only 2,000 who had not either served in the legions or received a legitimate vacatio. However, the scarcity of assidui who could be conscripted in that year was not due to any overall lack of men whose wealth qualified them for service in the legions but to an inability to conscript every assiduus without leaving many farms critically short of the labour required to work them and to support the families that depended on them for sustenance. ${ }^{142}$ For that reason, nearly half of all assidui at that point had been exempted from the draft. Much the same will have been true in 2 Iо B.C. It has long been recognized that slave labour played a major part in keeping the Roman armies paid (to the extent they were paid) and fed along with

\footnotetext{
138 Livy $26 \cdot 35 \cdot 2-3$.

139 Livy 29.I6.I-3, 3I.I3.I-9, 33.42.2-4.

140 CIL I.585 line 3I = M. Crawford (ed.), Roman Statutes, Vol. I (I996), II6-I7 line 3I, cf. I67-8.

141 Note, too, that a lack of slaves in 206 B.C. was among the reasons that refugees who had fled to Rome alleged were impeding their return to the countryside to resume cultivation of their farms: Livy 28.II.8-9.

142 N. Rosenstein, 'Marriage and manpower', Historia 5I (2002), I63-9I.
} 
the civilian population during the war. ${ }^{143}$ Citizens in the higher census classes certainly bore proportionately the heaviest share of financing the Roman war effort through their payment of tributum. They had already given up in addition a substantial number of slaves either to the fleet in 214 B.C. or to the two legions of volones levied in 216 B.C. after Cannae. To ask them now to give up more of their labour force would, in their view at least, cripple their ability to produce the food and pay the taxes that kept the Roman war effort going.

Yet there was perhaps an additional dimension to their reluctance further to deplete their labour force on the one hand but their willingness to lend the state money on the other: the fall of Syracuse in 2 I 2 B.C. and the infusion of bullion into the treasury as a result. One consequence of this was the revaluation of the coinage around this time through the introduction of the silver denarius and the sestantal as. ${ }^{144}$ With the coinage sound once again and the debasement of the preceding several years at an end, sale of their crops would have been particularly attractive to farmers not only to raise the money they needed for taxes (where they paid these in specie) but because additional crops could be exchanged for the new, sound money either to the government to meet its additional need for its commissariat or to refugees in Rome or elsewhere at a time when demand was high and the war effort had taken large numbers of men off their farms. Moreover, some of Italy's best agricultural land was at that point producing few if any crops. Campania had been ravaged during the years following Cannae, and Apulia was the scene of continuing fighting between Roman and Carthaginian forces. The market for agricultural products ought to have been strong, and so despite the heavy demands for taxes, those still in a position to meet this demand ought to have seen profits rise. Labour at that point, in other words, was more valuable than the money that would pay for it, and consequently farmers were readier to give up the latter in order to preserve the former, particularly when the amount of money they would be required to contribute was left up to their own discretion.

If we can understand the events of 2 го в.с. in this way, we are still left with the problem of the seemingly excessive numbers of slaves relative to the Republic's needs for oarsmen produced by the arrangements put in place in 2 I4 B.C. In all likelihood the arrangements that the Senate envisaged for conscripting sailors in 2I4 B.C. were more complex than Livy's text suggests and somewhat akin to the method of levying soldiers for the legions. In theory every Roman citizen below the age of forty-six was obligated to report to the magistrates raising an army in order to be considered for enrolment. In fact, men older than about thirty rarely were obligated to serve, but even those citizens between eighteen and thirty were far more numerous than were required for an ordinary annual levy. ${ }^{145}$ Yet whether they all travelled to Rome each year to present themselves for the levy or some preliminary selection was carried out closer to their homes by local officials, the legionary levy involved choosing recruits from a much larger pool of eligible citizens. ${ }^{146}$ The patres were similarly concerned in 2 I4 B.C. to provide a large pool of eligible slaves from whom the magistrates could pick the most suitable rowers. Slaveowners otherwise would have been tempted to send only their oldest, sickest, or most unsuitable slaves. Instead, they were required to provide a specific number of potential enlistees according to their census classification, of whom some or all or none might be selected. Equity was based on the idea that the more slaves a citizen presented as potential rowers, the greater the chance that one or more of them would be enrolled.

\section{Department of History, The Obio State University}

rosenstein.r@osu.edu

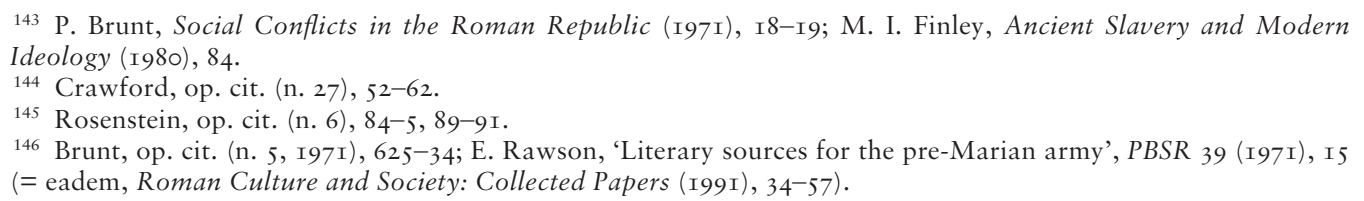

